\title{
Management of Rheumatoid Arthritis: Consensus Recommendations From the Turkish League Against Rheumatism
}

\author{
Romatoid Artritin Tedavisi: Türkiye Romatizma Araştırma ve \\ Savaş Derneği Uzlaşı Önerileri
}

\author{
Şebnem ATAMAN, ${ }^{1}$ Pınar BORMAN, ${ }^{2}$ Deniz EVCIK,,${ }^{3}$ Ece AYDOG,${ }^{4}$ Figen AYHAN,, 2 Derya YILDIZLAR, ${ }^{5}$ Hatice BODUR, ${ }^{6}$ \\ Zuhal ALTAY, ${ }^{7}$ Murat BİRTANE, ${ }^{8}$ Bülent BÜTÜN, ${ }^{9}$ Tuncay DURUÖZ,${ }^{10}$ Hatice Rana ERDEM, ${ }^{2}$ Zafer GÜNENDİ, ${ }^{11}$ \\ Rezzan GÜNAYDIN,${ }^{12}$ Gülcan GÜRER,${ }^{13}$ Cahit KAÇAR, ${ }^{9}$ Ece KAPTANOĞLU,${ }^{14}$ Taciser KAYA, ${ }^{12}$ Neşe ÖLMEZ, ${ }^{15}$ \\ Nurdan PAKER, ${ }^{16}$ Aylin REZVANİ, ${ }^{17}$ Birkan SONEL TUR, ${ }^{5}$ Mahmut YENER, ${ }^{18}$ Salih ÖZGÖÇMEN ${ }^{19}$
}

${ }^{1}$ Department of Physical Medicine and Rehabilitation, Medical Faculty of Ankara University, Division of Rheumatology, Ankara, Turkey; ${ }^{2}$ Department of Physical Medicine and Rehabilitation, Ankara Training and Research Hospital, Ankara, Turkey; ${ }^{3}$ Department of Therapy and Rehabilitation, Ankara University, Haymana Vocational School, Ankara, Turkey; ${ }^{4}$ Department of Physical Medicine and Rehabilitation, Medical Faculty of Yeditepe University, İstanbul, Turkey; ${ }^{5}$ Department of Physical Medicine and Rehabilitation, Medical Faculty of Ankara University, Ankara, Turkey; ${ }^{6}$ Department of Physical Medicine and Rehabilitation, Ankara Numune Education and Research Hospital, Ankara, Turkey; ${ }^{7}$ Department of Physical Medicine and Rehabilitation, Medical Faculty of Inönü University, Malatya, Turkey; ${ }^{8}$ Department of Physical Medicine and Rehabilitation, Medical Faculty of Trakya University, Edirne, Turkey; ${ }^{9}$ Department of Physical Medicine and Rehabilitation, Medical Faculty of Akdeniz University, Division of Rheumatology, Antalya, Turkey; ${ }^{\circ}$ Department of Physical Medicine and Rehabilitation, Medical Faculty of Celal Bayar University, Division of Rheumatology, Manisa, Turkey; ${ }^{1}$ Department of Physical Medicine and Rehabilitation, Medical Faculty of Gazi University, Division of Rheumatology, Ankara, Turkey; ${ }^{12}$ Department of Physical Medicine and Rehabilitation, İzmir Bozyaka Training and Research Hospital, İzmir, Turkey; ${ }^{13}$ Department of Physical Medicine and Rehabilitation, Van Training and Research Hospital, Division of Rheumatology, Van, Turkey; ${ }^{14}$ Department of Physical Medicine and Rehabilitation, Medical Faculty of Cumhuriyet University, Division of Rheumatology, Sivas, Turkey; ${ }^{15}$ Department of Physical Medicine and Rehabilitation, Izmir Atatürk Training and Research Hospital, Izmir, Turkey; ${ }^{16}$ Istanbul Physical Medicine and Rehabilitation Training and Research Hospital, Istanbul, Turkey; ${ }^{17}$ Department of Physical Medicine and Rehabilitation, Medical Faculty of Bezmialem Vakif University, İstanbul, Turkey; ${ }^{18}$ Department of Physical Medicine and Rehabilitation, Medical Faculty of Süleyman Demirel University, Isparta, Turkey; ${ }^{19}$ Department of Physical Medicine and Rehabilitation, Medical Faculty of Erciyes University, Division of Rheumatology, Kayseri, Turkey;

Objectives: Taking new developments in the management of rheumatoid arthritis (RA) and the economic conditions of our country into account, the Turkish League Against Rheumatism (TLAR) aimed to develop national treatment recommendations for the management of RA; thus, they consulted with national experts for their opinions.

Materials and methods: Eight rheumatologists and 15 physiatrists experienced in the field contributed to the development of the TLAR recommendations for the management of RA. The expert committee planned to develope "Recommendations for the Management of RA in Turkey" based on EULAR 2010 recommendations for the management of RA with synthetic and biological disease-modifying antirheumatic drugs (DMARDs) in light of expert opinions. Following the meeting, a systematic literature review was performed by searching the Medline and Cochrane, Embase, and Turkish Medical Index databases between 2009 and 2010 for pharmacological treatment recommendations and between 2007 and 2010 for non-pharmacological treatment recommendations. This was done in addition to the studies included in the EULAR 2010 recommendations. All articles were examined, their contents were summarized, their levels of evidence were determined, and the Delphi process was initiated.

Results: Sixteen general recommendations were listed along with five main principles and one non-pharmacological treatment method. A consensus was reached for all recommendations, and their strength levels were voted upon.

Conclusion: Recommendations were formed for the management of RA in Turkey. These national recommendations are intended to guide physical medicine and rehabilitation specialists (physiatrists), rheumatologists, and family physicians and should be regularly updated.

Key words: Guidelines; rheumatoid arthritis; treatment.
Amaç: Türkiye Romatizma Araştırma ve Savaş Derneği (TRASD) romatoid artrit tedavisindeki yeni gelişmeleri ve ülkemizin ekonomik koşullarını göz önünde bulundurarak, RA tedavisine yönelik ulusal tedavi önerileri geliştirmeyi amaçlamıştır ve bu amaçla, fikirlerini almak için ulusal uzmanlara danışmıştır.

Gereç ve yöntemler: Bu alanda deneyimli olan sekiz romatolog ve 15 fizik tedavi uzmanı TRASD'nin RA tedavisi önerilerinin geliştirilmesine katkıda bulunmuştur. Uzmanlar kurulu, EULAR 2010'da yer alan RA'nın sentetik ve biyolojik hastalık modifiye edici antiromatizmal ajanlarla (DMARD'ler) tedavi önerilerini baz alarak, uzman görüşlerinin de yer aldığı bir "Türkiye RA Tedavi Önerileri" oluşturulmasını planlamıştır. Toplantının ardından, Medline ve Cochrane, Embase ve Türk Tıp Dizini veritabanlarında farmakolojik tedavi önerileri için 2009 ile 2010 yılları arasını, non-farmakolojik tedavi için ise 2007 ile 2010 yılları arasını kapsayan aramalar gerçekleştirilerek sistematik bir literatür taraması yürütülmüştür. Bu işlem EULAR 2010 önerilerine dahil edilen çalışmalara ilave olarak yapılmıştır. Tüm makaleler incelenmiştir, içerikler özetlenmiştir, kanıt seviyeleri belirlemiştir ve Delphi işlemi başlatılmıştır.

Bulgular: Beş ana prensip ve bir non-farmakolojik tedavi yöntemiyle birlikte 16 genel öneri sıralanmıştır. Tüm öneriler konusunda uzlaşıya varılmıştır ve önerilerin kuvvet seviyeleri oylanmıştır.

Sonuç: Türkiye'deki RA tedavisine yönelik öneriler oluşturulmuştur. $\mathrm{Bu}$ ulusal önerilerin fizik tedavi ve rehabilitasyon uzmanlarına (fizyatri uzmanlarına) romatologlara ve aile hekimlerine yönelik bir kılavuz olarak işlev görmesi amaçlanmıştır ve önerilerin düzenli şekilde güncellenmesi gerekmektedir.

Anahtar sözcükler: Kılavuzlar; romatoid artrit; tedavi.

Correspondence: Şebnem Ataman, M.D. Ankara Üniversitesi Tıp Fakültesi Fizik Tedavi ve Rehabilitasyon Anabilim Dalı, Romatoloji Bilim Dalı, 06100 Sıhhiye, Ankara, Turkey. Tel: +90 312 - 5082542 e-mail: ataman.sebnem@gmail.com

(c)2011 Turkish League Against Rheumatism. All rights reserved. 
An absolute cure for rheumatoid arthritis (RA) is still not available. Management of the disease involves several treatment strategies targeting an expectation for disease remission. The treatment plan, constructed based on the knowledge, experience, and creativity of the involved clinicians, can be considered a work of art due to the diversity of RA treatment alternatives and the requirements involved in patient-specific treatment planning.

Up until now, several studies have been conducted and recommendations have been proposed as guidelines for the management of RA. Internationally well-known rheumatologists have published joint recommendations for the management of various rheumatic diseases. These recommendations provide guidance in terms of evidence-based medicine for all countries. Although these recommendations serve as the central focus of management when planning the treatment of RA, the geographic location of a country, the characteristics of RA patients, including lifestyle and environmental factors in that geographic region, and the operation of the healthcare system in that country bring up a need for the modification of its own therapeutic plans.

The Turkish League Against Rheumatism (TLAR), a scientific member of the European League Against Rheumatism (EULAR), produces scientific projects in the field of rheumatology in Turkey through its working groups and has become well-known for its national RA and ankylosing spondylitis (AS) registry systems. The organization has developed "Recommendations for the Management of RA in Turkey" based on international recommendations while also taking national conditions into account. In addition, expert opinions were also included in light of current evidence-based information.

\section{MATERIALS AND METHODS}

In April 2010, TLAR made a general announcement to members by e-mail to determine which experts desired to participate in the development of recommendations for the management of RA and requested for those who were interested to fill out a form consisting of their experience, knowledge, skills, and scientific publications in the field of RA. These forms were then analyzed and an expert committee was formed. A project manager and two assistant managers were assigned to coordinate the organization, form an e-mail network, and write the final manuscript. It was decided that they should not be involved in the process of the development of recommendations. A total of 24 individuals consisting of eight rheumatologists,
15 physical medicine and rehabilitation (PM\&R) specialists (physiatrists), and a PM\&R (physiatry) resident participated in the project.

The initial meeting was held in July 2010 in Ankara, and the RA experts were invited. The agenda included determining the aim of the project aim and the target audience. Also under discussion was a review of recent literature with a focus on recommendations and guidelines, the selection of pertinent recommendations and guidelines to be adopted which could serve as the fundamental basis for the development process, the determination of the headings and number of recommendations to be developed, and the achievement of a consensus on methodology.

It was decided that the essential objectives in developing these recommendations was to review the recent advances in the management of RA and their economic consequences under the framework of evidence-based medicine and expert opinion, develop a treatment algorithm for the management of RA in Turkey, and provide country-specific guidelines for the PM\&R specialists (physiatrists), rheumatologists, and family physicians.

A literature search was performed before the meeting to find all recent guidelines and recommendations so that they could be presented and discussed at the meeting. All of the recommendations suggested in the guidelines were examined during the meeting, and efforts were made to note which ones could be modified according to recent evidence and our national conditions while also allowing new recommendations to be implemented. It was also decided that "TLAR recommendations for the management of RA" should be prepared for presentation and publication so that it could be easily accessed by physicians interested in the field.

The recommendations included in four recent articles concerning the management of RA were presented to the expert committee in the meeting. 1- EULAR recommendations for the management of RA with synthetic and biological diseasemodifying antirheumatic drugs-2010, ${ }^{[1]}$ 2- Treating rheumatoid arthritis to target: recommendations of an international task force-2010, ${ }^{[2]} 3$ - ACR 2008 recommendations for the use of nonbiologic and biologic disease-modifying, antirheumatic drugs (DMARDs) in RA-2008, ${ }^{[3]}$ 4- Updated consensus statement on biological agents for the treatment of rheumatic diseases-2009. ${ }^{[4]}$ The last article included an update of previous recommendations. Participants 
from 23 different countries contributed to this update, and it not only included consensus recommendations for RA, but included recommendations for psoriatic arthritis and AS as well. Because this update only included biological agents and their adverse effects and did not embrace RA management as a whole, it was decided that this article should be used for the process of the development of recommendations in our project. ${ }^{[4]}$ The third article included the American College of Rheumatology (ACR) 2008 recommendations. These were listed for each medication in this article, and safety data for the biological agents was also included. Due to the limited number of recommendations in this article, which is only updated in certain years, and because the most recent update was slightly out-of-date, this article was used as a reference in our project but not as a primary source. The second article included the treatment recommendations of an international task force. They were developed using a Delphi-like procedure with the contributions of over 60 rheumatologists from different parts of the world and one patient. Four main principles and 10 recommendations were developed for targeting the treatment of RA. Therapeutic targets were defined as remission, with low disease activity being an alternative goal in patients with long-standing disease. The recommendations included the approach to the patient, therapeutic goals, and procedures to be followed to reach these goals. They included neither the names of drugs nor a specific treatment algorithm. It was decided that this article was important in terms of our project's objectives; however, a treatment algorithm which included specific drugs would have been more useful for guiding our physicians. Finally, the EULAR recommendations for the management of RA with synthetic and biological DMARDs were presented, and it was decided that they should serve as the fundamental basis for our own recommendations. It was emphasized that the EULAR recommendations did not include nonpharmacological treatment recommendations, nor did they include physical therapy, rehabilitative approaches, or other alternative treatment methods that are the basic fields of interest for PM\&R specialists who are also responsible for the treatment of RA patients in Turkey. These modalities are frequently used in the management of RA and should be included in the recommendations for our country. Therefore, it was decided to add one item consisting of non-pharmacological management of RA to the recommendations, and three more investigators were assigned to help in a systematic literature search about this topic.
Following the meeting, a systematic literature review (SLR) was performed by searching the Medline and Cochrane, Embase, and Turkish Medical Index databases between 2009 and 2010 for pharmacological treatment recommendations and between 2007 and 2010 for non-pharmacological treatment since studies up to June 2009 were included in the EULAR 2010 recommendations. The SLR included meta-analyses, systematic reviews, randomized controlled trials (RCTs), non-randomized controlled trials (nonRCTs), and observational studies, including data from registries. All articles were examined, their contents were summarized, and their levels of evidence were determined. The citation information of the articles, their summarized content, their levels of evidence, and the Turkish translation of the EULAR 2010 recommendations were e-mailed to all members of the expert committee, who were then asked to suggest five main principles, 15 pharmacological recommendations, and one non-pharmacological general recommendations based on the EULAR 2010 guidelines, evidence from recent literature, and their own expert opinions. The "Oxford Centre for EvidenceBased Medicine" ${ }^{[5]}$ was used to assess the strength of the recommendations and the level of evidence, and the Delphi technique ${ }^{[6]}$ was used to develop these recommendations. At the end of this process, a total of 17 main principles and 55 general recommendations were generated. These recommendations were re-grouped according to their content into five main principles and 16 general principles. In the first Delphi round, these recommendations were sent to all the experts, and they were asked to select one of the main principle subgroups and one of the general principle subgroups. Recommendations that were accepted by more than $60 \%$ of the experts in the Delphi round remained on the list with the remainder being removed. A total of three rounds were performed.

The second meeting of the expert committee was held in April 2011 in Ankara. Concise summary reports followed by the list of recommendations were presented by the project manager. The experts were asked to present their opinions and suggest necessary changes after the presentation of each recommendation. Every suggestion for change was voted on by the experts and accepted if it was voted for by more than $60 \%$. Each recommendation was then checked for spelling and grammar mistakes, and corrections were made so that the meaning was expressed in the best way. After these corrections were unanimously approved, the strength level of the recommendation (SOR) was voted on using 
electronic key pads. This procedure was repeated for each main principle and general recommendation. The completion of the whole process for the development of the recommendations took nearly 10 months.

\section{RESULTS}

The final version of the main principles and general recommendations that were listed in the second expert meeting is presented in Table 1. The strength of recommendation and levels of evidence for each recommendation are shown in Table 2.

\section{Main Principles}

A- The specialists primarily responsible for the management of patients with $R A$ are those experienced in rheumatic diseases. For our country, these specialists are rheumatologists and physical medicine and rehabilitation (PM\&R) specialists (physiatrists). In many countries, rheumatologists are the specialists who are primarily responsible for the management of RA. However, PM\&R specialists (physiatrists) have been primarily responsible for treating rheumatic diseases for a very long time in Turkey. In our country, PM\&R (as Physical Medicine/Therapy) was included as a medical specialty in the first regulation on specialty training in medicine dated May $8^{\text {th }} 1929$ that was implemented following the realization of Law No.1219 on the Practice of the Art of Medicine and its Branches, which forms the legal framework of modern medicine in Turkey. When subspecialties were first organized in 1961, PM\&R specialists who had systematically worked in the field of rheumatology were offered the title "rheumatologists". Rheumatology subspecialties were later founded under both Internal Medicine and PM\&R in 1983. ${ }^{[7]}$ Since then, it has been classified as such in all of the subsequent regulations on specialty training in medicine implemented in 1993, 2002, and 2009. ${ }^{[8]}$ The Ministry of Health and the Council of Higher Education (CHE) have approved the rheumatology divisions founded under PM\&R and internal medicine departments. This has been continuing as such since 1986. This evidence-based situation requires that RA should be treated by both rheumatologists and PM\&R specialists in Turkey.

$B$ - The management of patients with $R A$ should include the combination of pharmacological and non-pharmacological methods. Treatment should be planned on an individual basis for each patient. A patient-centered and multidisciplinary approach is essential for the management of RA. It is well-known that non-pharmacological treatment methods lead to improvement in patient function as do pharmacological treatment alternatives for this disease for which there is currently no cure. The expert committee decided that treatment should be planned on an individual basis for each patient taking several factors, such as disease activation, functional status, social life, and health insurance, into account.

\section{$C$. The management of patients with RA should} be executed using the best treatment alternatives available and taking into account current conditions. Treatment decisions should be made jointly by the patient and the specialist. Rheumatoid arthritis is a disease that may lead to irreversible structural damage if not properly treated. More effective treatment alternatives have been introduced for the management of RA in recent years. Current evidence suggests that these treatment agents prevent or reduce structural damage. Special care should be taken during treatment planning to provide the best treatment alternatives for the patient. This principle, which was included within the basic principles in the EULAR 2010 recommendations, was also accepted in the TLAR recommendations. ${ }^{[1]}$

D. Patients with RA and their families should be informed and educated, and social support should be provided for the patients. It has been demonstrated in numerous studies that educational-behavioral joint protection programs have beneficial effects on pain and disease activity (swollen and tender joint count) as well as functional and psychological status in RA. ${ }^{[9-11]}$ The experts wished to emphasize the beneficial effects of patient education on disease course in patients with RA. A multidisciplinary approach should be adopted, and education and support should be provided for the patient and family by a team composed of the patient's physician, nurse, physical therapist, nutrition specialist, occupational therapist, social worker, and psychologist. ${ }^{[12]}$

E. Rheumatoid arthritis is an expensive disease with regard to production costs of pharmacological agents and service costs of non-pharmacological agents. This should be considered by the treating specialist and team while also taking healthcare costs and reimbursement criteria, which may vary from country to country, into account. There has been a considerable amount of increase in medical treatment costs since the introduction of biological DMARDs in the management of RA. Health authorities in different countries have implemented different regulations and initiatives for the reimbursement of these agents. 
Table 1. Recommendations for the management of rheumatoid arthritis with pharmacological and non-pharmacological therapies

\section{Main Principles}

A. The specialists primarily responsible for the management of patients with rheumatoid arthritis (RA) are those experienced in rheumatic diseases. For our country, these specialists are rheumatologists and physical medicine and rehabilitation (PM\&R) specialists (physiatrists).

B. The management of patients with RA should include a combination of pharmacological and non-pharmacological methods. Treatment should be planned on an individual basis for each patient.

C. The management of patients with RA should be executed using the best treatment alternatives available and taking into account current conditions. Treatment decisions should be made jointly by the patient and the specialist.

D. Patients with RA and their families should be informed and educated and social support should be provided for the patients.

E. Rheumatoid arthritis is an expensive disease with regard to production costs of pharmacological agents and service costs of non-pharmacological agents. This should be considered by the treating specialist and team while taking healthcare costs and reimbursement criteria, which may vary from country to country, into account.

\section{General Recommendations for the Management of RA}

1. Synthetic disease-modifying, antirheumatic drug (DMARD) treatment should be started as soon as a diagnosis of RA has been made.

2. Treatment should target achieving remission or low disease activity as soon as possible in every patient. Patients should be strictly monitored every one to three months until these goals are reached.

3. The initial synthetic DMARD to be selected for monotherapy should be methotrexate (MTX) unless there is a contraindication or intolerance for MTX. Oral or injectable forms of MTX should be used both for monotherapy and in the context of combination treatment and in maximum tolerable doses, if necessary.

4. Leflunomide or sulfasalazine (SSZ) should be used as a part of the treatment strategy if MTX is contraindicated or cannot be tolerated. Antimalarial drugs can also be used in patients with mild disease.

5. Depending on the clinical characteristics in DMARD-naive patients, synthetic DMARD monotherapy should be used, irrespective of the addition of glucocorticoids (GCs).

6. In order to suppress inflammation more rapidly, low or moderate dose GCs are added to synthetic DMARD monotherapy or combination therapy. They provide the benefit of a short-acting initial treatment; however, they should be tapered as rapidly as possible.

7. The addition of a biological DMARD can be considered in patients for whom an initial DMARD strategy has failed to achieve the treatment target and for those who have poor prognostic factors. If there are no poor prognostic factors, switching to another synthetic DMARD should be considered.

8. In current practice, first-line biological DMARDs include TNF-alpha inhibitors (adalimumab, etanercept, infliximab) and they should be used in combination with MTX.

9. Other TNF inhibitors abatacept, rituximab or tocilizumab should be used in patients for whom the initial TNF inhibitor therapy has failed.

10. The use of synthetic DMARDs such as azathioprine, cyclosporin A (or cyclophosphamide in exceptional situations) can be considered in severe RA patients refractory to biological agents and synthetic DMARDs. However, severe toxicity profiles should be kept in mind.

11. Although patients with poor prognostic factors have more to gain from intensive medication strategies, these strategies should be considered for all patients.

12. If a patient using a biological DMARD, synthetic DMARD and GC is in remission, first the GCs should be tapered and discontinued, and then the biological DMARDs should be tapered if remission persists. Synthetic DMARDs should be continued at the same dosage throughout this process.

13. Tapering synthetic DMARD doses can be considered in patients with persistent longstanding remission, and the process can be planned by the patient and the doctor.

14. Different factors such as progression of structural damage, accompanying diseases and safety issues should also be considered during treatment planning.

15. Intraarticular local corticosteroids can be used in cases of monoarthritis.

16. Patient specific exercises, assistive and adaptive devices, protective and/or corrective ortheses, physical therapy modalities, balneotherapy, spa therapy and hydrotherapy should be used as non-pharmacological treatments in RA. 
Table 2. Strength level of main principles and general recommendations

\begin{tabular}{|c|c|c|c|}
\hline Recommendations & Level of evidence & Grade of recommendation & Strength of recommendation (SOR) \\
\hline 1 & 1a & A & $9.61 \pm 0.98$ \\
\hline 2 & $1 b$ & $\mathrm{~A}$ & $9.56 \pm 0.98$ \\
\hline 3 & 1a & A & $9.17 \pm 1.50$ \\
\hline 4 & 1a & A & $9.83 \pm 0.38$ \\
\hline 5 & 1a & $\mathrm{A}$ & $8.89 \pm 0.96$ \\
\hline 6 & 1a & A & $9.22 \pm 1.55$ \\
\hline 7 & 5 & $\mathrm{D}$ & $9.67 \pm 0.59$ \\
\hline 8 & $1 b$ & $\mathrm{~A}$ & $9.72 \pm 0.57$ \\
\hline 9 & $1 b$ & A & $9.22 \pm 1.17$ \\
\hline 10 & la & B & $9.11 \pm 1.02$ \\
\hline 11 & $1 b$ & B & $9.50 \pm 0.86$ \\
\hline 12 & $3 b, 1 b^{*}$ & $\mathrm{~B}$ & $8.78 \pm 1.86$ \\
\hline 13 & 4 & $\mathrm{C}$ & $9.39 \pm 0.85$ \\
\hline 14 & $3 b$ & $\mathrm{C}$ & $9.67 \pm 0.59$ \\
\hline 15 & $1 b$ & $\mathrm{C}, \mathrm{D}$ & $8.50 \pm 2.15$ \\
\hline 16 & $1 \mathrm{a}^{\star *} 1 \mathrm{~b} \dagger$ & $\mathrm{B} \ddagger, \mathrm{Cg}$ & $8.22 \pm 1.80$ \\
\hline
\end{tabular}

The reimbursement criteria have increasingly made it difficult to use these agents in our country over the past several years. However, sick leaves and disability pensions have increased parallel with increased disease duration, even in countries where more effective drugs and appropriate treatment strategies are utilized with greater ease. ${ }^{[13]}$ Therefore, as mentioned in the EULAR recommendations, ${ }^{[1]}$ the expert committee wishes to emphasize that direct and indirect costs of RA, especially if insufficiently treated, are very high in our country where the use of more effective biological DMARDs is restricted.

\section{General Recommendations}

\section{Synthetic DMARD treatment should be started as} soon as a diagnosis of $R A$ has been made. Rheumatoid arthritis is a disease associated with increased risk for disability and early death. The mainstay of pharmacological treatment of RA is to ameliorate synovitis, which may cause joint destruction, as early as possible. It has been shown that initiation of DMARD treatment immediately after disease onset is associated with a better outcome compared with later usage. ${ }^{[14]}$ Synthetic DMARDs are known to improve symptoms, articular findings, and physical function while also slowing down radiological progression. ${ }^{[15-17]}$ Thus, the initial treatment approach should include synthetic DMARDs due to the high cost of biological DMARDs, which are also known to be effective in the early stage of the disease. It has been emphasized in several articles in which recommendations for the management of RA are published (i.e. EULAR, ACR, Sweden) that treatment with a synthetic DMARD should be initiated as quickly as possible after the diagnosis of RA..$^{[1,3,18]}$ Our expert committee unanimously approved this opinion.

\section{Treatment should target achieving remission} or low disease activity as soon as possible in every patient. Patients should be strictly monitored every one to three months until these goals are reached. It has been shown that treatment need in patients with RA is not adequately met, and most patients have moderate disease activity. ${ }^{[19]}$ High disease activity and persistent moderate activity in DAS-28 scores are associated with significant functional deterioration. It is also known that functional impairment may occur even in low activity status. ${ }^{[20]}$ Therefore, the primary goal should be to achieve remission. Low disease activity may be an acceptable target in cases where remission cannot be reached. It has been clearly demonstrated in the FIN-RACo (FINish Rheumatoid Arthritis Combination Therapy), TICORA (Effect of a treatment strategy of tight control of rheumatoid arthritis), BeST (Clinical and radiographic outcomes of four different treatment strategies in patients with early rheumatoid arthritis), and CAMERA (Computer Assisted Management in Early Rheumatoid Arthritis) 
trials that strict monitorization of the patients is effective in reaching this target. ${ }^{[21-24]}$ The CAMERA study suggested the importance of monthly assessments using an objective computer software model developed for this purpose.

3. The initial synthetic DMARD to be selected for monotherapy should be methotrexate (MTX) unless there is a contraindication or intolerance. Oral or injectable forms of MTX should be used both for monotherapy and in the context of combination treatment in maximum tolerable doses, if necessary. Methotrexate is the most effective drug among the DMARDs and is recommended for use as the initial choice of treatment in order to control disease activity within the shortest period of time. ${ }^{[25-27]}$ It has been found that MTX is used more commonly than other DMARDs in patients with high disease activity. ${ }^{[27]}$ When considering efficacy/toxicity ratio analyses, it has been demonstrated that MTX used for monotherapy is as beneficial as when it is used in combination treatment, and it definitely downgrades radiological disease progression. ${ }^{[28,29]}$ Methotrexate is also the most frequently used drug in combination treatment with DMARDs and biological agents. The DMARD combination is often used as a second treatment step if there is no response to MTX monotherapy. ${ }^{[30]}$ In addition, the effectiveness of MTX increases and the adverse effect profile does not change when it is used in combination with parenteral gold and other DMARDs. ${ }^{[31]}$ It can be used orally and subcutaneously. ${ }^{[32]}$ According to the reimbursement criteria of our country, the initial use of MTX in RA treatment has to be in an oral form; however, subcutaneous forms can be used if the oral form cannot be tolerated. Methotrexate used subcutaneously has been found to be superior in terms of both efficacy and safety. ${ }^{[25]}$ Although MTX can be used in weekly doses of 7.5-30 mg, doses up to $25 \mathrm{mg}$ are more common. Its efficacy is increased when used in combination with anti-tumor necrosis factor (antiTNF) agents along with other biological agents. ${ }^{[33,34]}$ Therefore, the use of MTX in combination with most of the biological DMARDs has been approved by the Food and Drug Administration (FDA). Moreover, it also reduces autoantibody formation against biological agents when used in combination with these drugs. ${ }^{[35]}$

4. Leflunomide or sulfasalazine (SSZ) should be used as a part of the treatment strategy if MTX is contraindicated or cannot be tolerated. Antimalarial drugs can also be used in patients with mild disease.
Leflunomide is often used as the first choice of DMARDs following MTX. ${ }^{[36]}$ It is effective in the treatment of patients with RA as a monotherapy or in combination with MTX and is well tolerated. ${ }^{[37]}$ It has a comparable efficacy with MTX in the treatment of RA, and it has also been demonstrated to be effective when used in combination with biological agents, Its safety has been proven with regular controls. In a recent study, the combination of leflunomide with rituximab was shown to be superior to the MTX/rituximab combination. ${ }^{[36]}$ It has been reported to reduce radiological progression compared with a placebo, but when compared with MTX and SSZ, no reduction was seen. ${ }^{[38,39]}$ Significant improvement in functions and Health Assessment Questionnaire (HAQ) scores have been demonstrated in patients using leflunomide compared with a placebo. ${ }^{[40]}$ In another study, improvement in physical functions lasting 24 months was noted with MTX, leflunomide, and SSZ. ${ }^{[41]}$ Sulfasalazine has been proven to be an effective drug in the treatment of RA by placebocontrolled studies. ${ }^{[42-44]}$ In various clinical trials, SSZ has been shown to induce improvement in disease parameters similar to those observed by penicillamine, hydroxychloroquine (HCQ), and oral or parenteral gold ${ }^{[45]}$ while comparative metaanalyses have concluded that it can be listed among the more effective DMARDs. ${ }^{[46]}$ Sulfasalazine also slows down radiological progression in RA. ${ }^{[4]}$ Chloroquine (CQ) and hydroxychloroquine (HCQ) are antimalarial drugs used in the treatment of RA. As HCQ is less toxic than CQ, it is more commonly preferred despite its lower efficacy. ${ }^{[48]}$ In a systematic meta-analysis of four comparative studies, HCQ was found to be more effective than a placebo in RA. It was concluded that though it has moderate efficacy, it should be considered for use in the treatment of RA due to its low toxicity profile. ${ }^{[49]}$ It is frequently included in combination treatment regimens associated with successful outcomes. ${ }^{[50]}$ In Turkey, HCQ is occasionally chosen as an initial DMARD in patients who have mild disease activity and do not possess any poor prognostic factors. Although oral and parenteral gold are included in the EULAR recommendations, ${ }^{[1]}$ they are not readily available and are not frequently used in our country. This is especially true since treatment with MTX has become widely popular. Thus, CQ and HCQ have not been included in the national recommendations by the expert committee. 
5. Depending on the clinical characteristics in DMARD-naive patients, synthetic DMARD monotherapy or combination therapy should be used, irrespective of the addition of glucocorticoids (GCs). It has been demonstrated in several clinical studies that DMARD monotherapy is superior to a placebo, and DMARD combination therapy leads to more favorable outcomes compared with monotherapy. Combination therapy, either with or without GCs, has also been shown to be more cost-effective compared with monotherapy. ${ }^{[51]}$ In most of the combination treatment trials, such as the COBRA (Combination therapy in patients with early rheumatoid arthritis) study by Boers et al., ${ }^{[52]}$ the CIMESTRA (Cyclosporine, methotrexate, and steroid in rheumatoid arthritis) study by Hetland et al. ${ }^{[53]}$ and the FIN-RACo study by Möttönen et al. ${ }^{[54]}$ GCs have been included in DMARD treatment regimes. ${ }^{[21,52-54]}$ There have also been studies demonstrating the effectiveness of combination treatment without the addition of GCs. In two different studies by Dougados et al. ${ }^{[55]}$ and Haagsma et al., ${ }^{[56]}$ the combination of SSZ and MTX was compared with monotherapy, and the combination treatment was shown to be more effective. ${ }^{[5,56]}$ Calgüneri et al. ${ }^{[57]}$ compared monotherapy with two- and three-drug combination therapies. The three-drug combination therapy was shown to be more effective than the twodrug combination, and the two-drug combination was more effective than monotherapy. ${ }^{[57]}$ In another study, a three-DMARD combination was compared with an intensive, step-up DMARD treatment, and both regimens were found to provide similar efficacy in controlling disease activity ${ }^{[58]}$ It is important to assess the presence of poor prognostic criteria in DMARDnaive patients during clinical decision making for the initiation of either monotherapy or combination treatment.

6. In order to suppress inflammation more rapidly, low or moderate dose GCs are added to synthetic DMARD monotherapy or combination therapy. They provide the benefit of a short-acting initial treatment; however, they should be tapered as rapidly as possible. Glucocorticoids are often used in low doses and in combination therapies with RA. Doses of 10 $\mathrm{mg}$ or lower of GCs are rather effective in improving the symptoms in active RA. However, most patients become functionally dependent on the long-term use of these drugs. ${ }^{[59]}$ The EULAR recommendations regarding the use of GCs in RA were developed after a wide systematic search of literature between 1962 and 2009. It was suggested in those recommendations that the use of GCs may provide the benefit of a bridge therapy in patients who have recently started to receive DMARDs. The addition of GCs to synthetic DMARDs is helpful considering its effects on the symptoms, findings, and function. Radiological progression especially benefits from the GCs. The inhibition of radiographic progression may continue for years, and GCs should be tapered as rapidly as possible, though gradually, to avoid clinical activation. ${ }^{[60]}$ In another article of systematic review and expert opinions about the use of GCs in early RA, it was recommended that GCs could be used in low or moderate doses in cases with inadequate response to non-steroidal antiinflammatory drugs (NSAIDs) and active disease or for a limited time as a bridge therapy until the effects of DMARDs are observed. The dosage should be tapered in accordance with the clinical situation, and the goal should be to stop taking the drug completely. ${ }^{[61]}$ It has been suggested in the National Institute for Clinical Excellence (NICE) guideline for the management of RA that the use of long-term, low-dose GC in the treatment of early onset and established RA may be acceptable, but it is not ideal for patients who become dependent on this treatment in routine clinical practice because their disease is exacerbated when they stop taking GCs. The NICE guideline suggests that efforts should always be made to replace GCs with other DMARDs, and GC doses should be kept at a minimum level. ${ }^{[62]}$ The rationale behind efforts for the use of short-term, low-dose GCs stems from concerns about long-term safety. According to a meta-analysis of 14 studies, most of which included low-dose and long-term GC usage in patients with RA, the annual incidence of adverse effects was found to be 43/100 (95\% CI: 30-55). The annual incidence reached much higher values in highdose GC therapies, such as 555/100 (95\% CI: 391-718) in inflammatory bowel disease. ${ }^{[63]}$ In accordance with these findings, the expert committee has agreed that GCs should be used in low doses.

7. The addition of a biological DMARD can be considered in patients for whom an initial DMARD strategy has failed to achieve the treatment target and for those who have poor prognostic factors. In cases without poor prognostic factors, switching to another synthetic DMARD should be considered. Biological DMARDs have a more rapid effect on disease activity compared with synthetic DMARDs in early RA. Also, biological agents are more effective in stopping radiological progression when used as monotherapy. They are even more efficacious when used in combination with MTX. Basic radiological 
scoring, swollen joint count, erythrocyte sedimentation rate (ESR), C-reactive protein (CRP) levels, and the presence of anti-cyclic citrullinated protein (antiCCP) antibodies in patients with early RA can be used to estimate which patient may exhibit a more rapid disease progression and joint destruction. ${ }^{[64-66]}$ The Abatacept Study to Gauge Remission and Joint Damage Progression in Methotrexate-Naive Patients with Early Erosive Rheumatoid Arthritis (AGREE) showed that the early use of a biological agent + MTX combination resulted in a better patient outcome than when the agents were added later. ${ }^{[67]}$ The Early Rheumatoid Arthritis (ERA) study was the first study to compare etanercept and MTX monotherapy in early RA, and it noted a more rapid improvement and cessation of radiological progression in the etanercept arm. ${ }^{[68]}$ The combination of infliximab and MTX was found to be superior to MTX alone in the ActiveControlled Study of Patients Receiving Infliximab for Treatment of Rheumatoid Arthritis of Early Onset (ASPIRE) study. ${ }^{[69]}$ The PREMIER study was a multicenter, randomized double-blind study comparing the use of MTX alone, adalimumab alone, and the combination of adalimumab + MTX in MTX-naive patients with early aggressive RA. It was found that the adalimumab + MTX combination was superior to the other monotherapies in early aggressive RA in terms of improvement of symptoms and findings, inhibition of radiological progression, and establishing clinical remission. ${ }^{[7]}$ In another study, the adalimumab + MTX combination was found to be superior compared with MTX monotherapy in slowing down radiological progression in patients with early RA. ${ }^{[71]}$ A metaanalysis of seven combination studies involving infliximab, adalimumab, etanercept, or abatacept concluded that the combination of biological agents and MTX was superior to MTX monotherapy in terms of establishing remission. ${ }^{[72]}$ Four different treatment strategies were compared in the BeST study, and earlier functional improvement and less radiological damage were noted at the end of one year in the group treated with a combination of biological agents compared with successive monotherapy or step-up combination treatment groups. $^{[73]}$ The rationale behind this recommendation has been presented in detail in the EULAR recommendations. No randomized controlled or observational studies have been conducted to test different treatment agents based on prognostic factors; however, this recommendation was based on expert opinion supported by indirect evidence. We also found no study addressing this aspect during our literature search; therefore, our expert committee accepted this statement based on expert opinion as previously stated. ${ }^{[1]}$

\section{In current practice, first-line biological DMARDs} include TNF-alpha inhibitors (adalimumab, etanercept, infliximab), and they should be used in combination with MTX. Tumor necrosis factor a (TNF-a), which was originally defined in the 1970s, is a pro-inflammatory cytokine that plays a central role in RA pathogenesis. ${ }^{[74]}$ It was the first of the biological agents to be used in RA treatment following classical DMARDs. Maini et al. ${ }^{[75]}$ evaluated the effects of antiTNF treatment, both with and without MTX, in a phase II study in 1998. This study has served as the basis for the development of infliximab treatment protocol since that time. ${ }^{[75]}$ Following that trial, Moreland et al. ${ }^{[76]}$ reported in another phase II study that etanercept was a safe drug with rapid, significant, and ongoing efficacy in patients with RA. The ASPIRE study showed that infliximab was superior to MTX. ${ }^{[69]}$ In another study conducted involvinig MTX using RA patients with active disease, it was found that the percentage of patients achieving American College of Rheumatology (ACR) 20 response was $70 \%$ in the etanercept and MTX group, but only $27 \%$ achieved this response in the placebo group. ${ }^{[7]}$ It was reported in the Trial of Etanercept and Methotrexate with Radiographic Patient Outcomes (TEMPO) study that both clinical and radiological response was greater in patients receiving etanercept and MTX combinations. ${ }^{[78]}$ Adalimumab is a human anti-TNF monoclonal antibody. Its efficacy in RA was investigated in the anti-TNF research study program of the monoclonal antibody adalimummab (DTE7) in rheumatoid arthritis (ARMADA) trial and the PREMIER study, and it was found that it was more effective than MTX as a monotherapy agent. It was also superior to monotherapy when combined with MTX. ${ }^{[0,79]}$ These three anti-TNF agents were the first drugs proven to be effective for RA and approved by the FDA to be used in its treatment. Their efficacy has been demonstrated in numerous studies. ${ }^{[35]}$ Adalimumab, etanercept, and infliximab are the TNF inhibitors which are reimbursed by the Social Security Institution in Turkey; therefore; they are the most frequently prescribed drugs. Other TNF inhibitors, such as golimumab, have been approved for use in the treatment of RA, but the costs are not yet covered by our insurance system. There are still no comparative studies which suggest that other biological agents used in the treatment of RA are superior to anti-TNF agents. Therefore, the expert committee decided that 
the initial biological DMARDs to be used following synthetic DMARDs should be anti-TNF agents.

9. Other TNF inhibitors (abatacept, rituximab or tocilizumab) should be used in patients for whom the initial TNF inhibitor therapy has failed. Due to their disparate structures, TNF-blocking agents have similar effects on the same target molecule through diverse pathways. ${ }^{[80]}$ In addition to the alterations in their molecular structure, differences in terms of a patient's specific genetic features, antibodies which may develop against the drugs, dosage regimens, and pharmacokinetic characteristics may also lead to variations in the efficacy of these drugs with individual patients (a lack of response, adverse affect etc). ${ }^{[81]}$ In the Finnish Register of Biological Treatment (ROB-FIN) study conducted on 1688 patients of the Finnish Biological Therapy Registry System, switching from one biological agent to another was noted in $37 \%$ of the patients during a follow-up period of 28 months, and the most effective results were obtained in the case of loss of effect to the first anti-TNF drug. ${ }^{[82]}$ Scrivo et al. ${ }^{[83]}$ reported switching to a second anti-TNF drug in 37 out of 692 registered anti-TNF-alpha-naive RA patients. Remission and low disease activity along with good and moderate/ good EULAR response rates were elevated after three months. Some studies have suggested that anti-TNF drugs are more effective with anti-TNF-naïve patients compared with their use as a switching agent. When the switch to another anti-TNF agent was performed due to a lack of effect or an adverse effect, the risk for drug cessation was shown to increase due to the same reasons. ${ }^{[84-86]}$ An analysis of the Danish Database for Biological Therapies in Rheumatology (DANBIO) showed that patients with RA benefit from the switching of anti-TNF drugs. ${ }^{[87]}$ Active RA patients refractory to DMARD or TNF blockers were included in a rituximab meta-analysis, and ACR 20, 50, and 70 responses were evaluated. Rituximab and MTX combination treatment was found to be effective and associated with low adverse effect incidence in refractory cases. ${ }^{[88]}$ It was suggested in a consensus report on rituximab that the drug, when used in combination with MTX, is effective in patients refractory to other biological agents, especially in seropositive RA, but there is insufficient data regarding the optimal dose. ${ }^{[89]}$ Schiff and Bessette ${ }^{[90]}$ have used abatacept, another biological agent, and a MTX combination in biological DMARD-naïve active RA patients with insufficient response to MTX and have demonstrated significant improvement in radiological progression along with clinical response. Similarly, improvement in the DAS-28 score and clinical activity has been demonstrated by tocilizumab (TCZ) treatment in patients refractory to TNF blockers. ${ }^{[91]}$ When evaluated based on DAS28 and the EULAR remission criteria, TCZ was found to be clinically effective and safe when used alone or in combination with MTX in patients refractory to other TNF blockers. ${ }^{[92]} \mathrm{A}$ Cochrane review on the use of TCZ in the treatment of RA suggested that TCZ delays radiological progression and can be used effectively, especially in active RA patients unresponsive to DMARDs like MTX or in some patients unresponsive to anti-TNF agents. However, further studies are needed in terms of safety. ${ }^{[93]}$ The biological treatment spectrum, which began with the introduction of anti-TNF agents in the management of RA, has grown over time due to the treatment success achieved by the new drugs. Currently, rituximab, abatacept, and tocilizumab have also proven their efficacy in RA management.

10. The use of synthetic DMARDs such as azathioprine, cyclosporin $A$ (or cyclophosphamide in exceptional situations) can be considered in severe $R A$ patients who are refractory to biological agents and synthetic DMARDs. However, severe toxicity profiles should be kept in mind. Intolerance to synthetic DMARDs or inefficacy can be an issue in RA treatment. In this case, biological agents are preferred. Some of the recent studies have shown that inefficacy or resistance to treatment can be a problem in patients using TNF blockers. ${ }^{[94,95]}$ Cyclosporin-A (CsA) is one of the synthetic drugs which can be used in these situations. It essentially acts on T-cells and inhibits IL-2 release, which subsequently reduces T-cell activation. ${ }^{[96,97]}$ Previous CsA-related studies have shown that it is effective in low doses in RA patients. Favorable results have been achieved by its combination with MTX, especially in severe RA patients refractory to MTX treatment. ${ }^{[98,99]}$ Guidelines for the use of CsA were updated by Newsome in 2002, and it has been effective in refractory RA patients as a monotherapy. ${ }^{[100]}$ Placebo-controlled trials with CsA have shown that it is also associated with a decrease in radiological progression. ${ }^{[101]}$ In a doubleblind, randomized, placebo-controlled trial comparing CsA monotherapy with the combination of CsA and MTX, the combination treatment was shown to have similar efficacy, with the reduction in radiological progression being greater than in monotherapy. ${ }^{[102]}$ In another study, CsA monotherapy was compared to 
the combination therapies of CsA plus MTX and CsA plus HCQ in patients with early RA. The combination of CsA and MTX was found to be significantly more effective in terms of ACR 50 response and radiological progression. ${ }^{[103]}$ Shah et al. ${ }^{[104]}$ investigated the efficacy and safety profile of CsA use in patients with RA. They noted clinical improvement and a reduction in radiological progression by CsA in patients with RA who were refractory to other DMARDs. Tolerability was noted to be higher compared with other studies. It was reported in a meta-analysis that the use of CsA was effective on clinical manifestations in severe patients with active RA. ${ }^{[105]}$ However, a common feature in studies involving CsA is that this treatment protocol should be used with extreme caution when other adverse effects, such as hypertension and nephrotoxicity, are reported. Azathioprine (AZT) is another drug that can be used in refractory cases. It is a purine analog which acts by the inhibition of DNA synthesis and has an immunosuppressive effect on T-lymphocytes. The use of AZT in RA management has been investigated in several studies and has been noted to be especially effective in cases with vasculitis. ${ }^{[106]}$ These studies have been conducted in small patient samples; therefore, AZT has not been primarily included in RA treatment regimens due to severe toxicity. ${ }^{[99,106]}$ There is not enough data regarding its beneficial effect on radiological progression, and its high toxicity profile has limited its use in patients with severe refractory cases of RA. ${ }^{[107]}$

In placebo-controlled trials, reduction in tender and swollen joint count has been demonstrated by the use of cyclophosphamide (an anti-neoplastic agent) in RA. However, it is recommended to be used with caution due to severe toxicity issues and by taking the benefit-to-harm ratio into account. ${ }^{[108]}$

11. Although patients with poor prognostic factors have more to gain from intensive medication strategies, these strategies should be considered for all patients. High radiological scoring, swollen joint count, ESR, CRP, and anti-CCP levels at baseline as well as female gender and poor functional status are known as prognostic factors in RA suggesting a rapid progression and more destruction. It is recommended that intensive treatment strategies including a combination of DMARDs with antiTNF agents should be used in these patients from the beginning. ${ }^{[1]}$ These combinations are preferable for patients with high disease activity or progressive structural damage and for those who are refractory to DMARDs. ${ }^{[109]}$ However, combining DMARDs with each other or with low-moderate dose GCs along with tight monitoring and rapid switching of treatments are also considered to be intensive treatment strategies. ${ }^{[1]}$ The main goals of RA management are the prevention of joint destruction and irreversible disability by early diagnosis and the early initiation of aggressive treatment. Studies have shown that the combination of anti-TNF agents with DMARDs, such as MTX or leflunomide, increases remission rates and reduces disease activity and joint destruction. ${ }^{[110]}$ Kauppi et al. ${ }^{[111]}$ have reported that intensive DMARD treatments may prevent complications such as atlantoaxial subluxation which causes significant morbidity and mortality It has also been reported that the combination of synthetic DMARDs and GCs may be as effective as the anti-TNF and DMARD combination. ${ }^{[112-115]}$ The use of GCs as bridge therapy in combination with DMARDs has been shown to reduce radiological progression (Evidence level: 1A). ${ }^{[16,117]}$ A combination therapy of DMARDs and GCs in early RA has been suggested to improve the quality of life by reducing structural damage and disability. ${ }^{[117]}$ Combinations of two or three DMARDs are recommended for patients with moderate-high disease activity and poor prognostic factors. Combinations of MTX + HCQ and MTX + LEF have long been recommended for use in patients with active disease, regardless of prognostic factors. The combination of MTX + SLZ is also recommended for patients with active disease independent of disease duration and prognostic factors. The combination of three DMARDs such as MTX + SLZ + HCQ has been recommended in all patients with active disease and poor prognostic factors, regardless of disease duration. ${ }^{[3,58,59,118]}$

It has been reported in some power Doppler imaging studies that there is ongoing synovitis, even in patients under remission. ${ }^{[19]}$ Moreover, it has also been suggested in several recent studies that it would not be appropriate to characterize biological agents as undeniably more clinically effective than synthetic DMARDs. ${ }^{[120]}$ From this perspective, the use of two or three DMARDs in combination with GCs or the combination of a DMARD with an antiTNF agent, both of which may be characterized as intensive treatment, is recommended in all patients in the active or therapeutic window period. ${ }^{[121]}$ It has been shown in MTX studies that the addition of a DMARD does not reverse disease progression in patients not responding to MTX as monotherapy. ${ }^{[122]}$ It was reported in the FINRACo and BeST studies 
conducted using the Finnish registry of RA patients that early DMARD combination treatments were more effective in attaining low disease activity and remission compared with DMARD monotherapies, and the effect lasted for a longer period of time. ${ }^{[123,124]}$ The CAMERA study conducted using the Dutch registry showed that remission rates were higher in RA patients under intensive treatment and tight monitoring of monthly follow-up. ${ }^{[24]}$ Ferraccioli et al. ${ }^{[125]}$ and Verschueren et al. ${ }^{[126]}$ also reported that intensive treatment was more effective and was associated with more rapid clinical response. Also, Donahue et al. ${ }^{[127]}$ suggested that combination therapies with DMARDs were more effective, but adverse effects should be carefully monitored. According to the ACR 2008 guidelines for the use of biological and non-biological DMARDs, two-drug combinations (MTX + HCQ, MTX + LEF, or HCQ + SLZ) were recommended for RA patients with moderate or high disease activity independent of prognostic factors (Evidence level: B). Again, in the same guidelines, the MTX + SLZ+ HCQ combination was recommended in cases of high disease activity without taking prognostic factors into account (Evidence level: C). ${ }^{[3]}$ However, it was also emphasized based on current evidence that DMARD and anti-TNF combinations should be reserved for more resistant patients in terms of cost effectiveness. In any case, the reimbursement system in our country has not approved for this combination treatment to be used in the early disease phase. Otherwise, intensive treatments, such as multiple DMARDs together with GCs, should be considered within the context of early aggressive treatment in all patients with high disease activity without considering the patient's prognostic factors. ${ }^{[1]}$ Taking all of the above-mentioned evidence into account, our expert committee supported this statement by $9.5 / 10$.

12. If a patient using a biological DMARD, synthetic DMARD, and GC is in remission, first the GCs should be tapered and discontinued, and then the biological DMARDs should be tapered if remission persists. Synthetic DMARDs should be continued at the same dosage throughout this process. It is currently not clear how to continue or discontinue drug treatment in patients who have attained remission. In guidelines for the use of GCs in RA, it has been emphasized that adverse effects in terms of osteoporosis, diabetes, and cardiovascular diseases should be monitored, and they should be tapered and finally discontinued as soon as the disease activation is suppressed. ${ }^{[66,128]}$ However, there is insufficient data regarding how the GC dose should be tapered and discontinued. ${ }^{[128]}$ It was concluded in a meta-analysis that the tapering and cessation of DMARD treatment in patients who had achieved remission was associated with an increased risk for disease activation and progression (Evidence level: 1a). ${ }^{[129]}$ It was reported in recently published data from the BeST study that DMARD therapy had to be reinstituted due to a relapse in $46 \%$ of the RA patients whose DMARD treatment was tapered when in remission, but radiological progression was not noted in these patients with tight monitoring during the drug-free period (Evidence level: B). ${ }^{[130]}$ It was emphasized that in patients with advanced RA, the same drugs should be continued at the same doses if remission was achieved by DMARD combination treatments. It has also been suggested that modifications such as dose reduction and drug cessation be made in patients under intensive treatment and tight monitoring; however, this recommendation has not been carried out due to lack of evidence. ${ }^{[131,132]}$ The most important aspect regarding this issue is the duration of remission. Reduction in the synthetic or biological DMARD dosage can be performed in cases of persistent remission, otherwise stated as remission for at least 12 months. However, GCs should be tapered first due to their worse adverse effect profile. [1] This was discussed in detail in statement No 6 . Biological agents can then be slowly tapered by expanding the treatment intervals and then finally discontinuing them. According to the five-year results of the BeST study, remission was achieved in $48 \%$ of the patients by the use of biological agents in the early period, and this remission persisted following the cessation of the biological agent in 19\% of the patients. ${ }^{[133]}$ In another arm of the BeST study, the biological agent was discontinued in patients using infliximab who had low disease activity for six months, and remission persisted in $52 \%$ of these patients. In those patients experiencing disease activation, low disease activity was achieved again in $84 \%$ of the patients by reinstitution of the infliximab treatment, and no radiological progression was noted during this interval. ${ }^{[132]}$ It is currently not clear how to expand the biological agent treatment intervals or discontinue drug treatment in patients who have attained remission. It is important that DMARDs should be continued at the same dosage level, and the patient should be monitored very frequently while reducing the biological agent dosage so that there will not be any disease activation..$^{[1,133]}$ Taking all of the 
above-mentioned evidence into account, our expert committee supports this statement by $8.78 / 10$.

\section{Tapering synthetic DMARD doses can be} considered in patients with persistent, longstanding remission, and the process can be planned by the patient and the doctor. As was discussed in the previous statement, DMARD doses can be readjusted in patients with longstanding remission under combination treatment after the discontinuation of GCs and biological agents. Patient characteristics, preferences, and dosage details should be taken into account during this process. It was reported in a recent study that disease flare was noted in half of the patients after the discontinuation of DMARDs due to longstanding remission, and DMARD treatment had to be reinstituted. However, it was also noted that if the flare was detected early by tight control and DMARDs were initiated at that point, radiological damage did not progress during the drug-free period in these patients. ${ }^{[130]}$ It was reported in a meta-analysis that reducing the DMARD doses or suddenly discontinuing them altogether led to disease activation, and it became more difficult and took more time to achieve remission after reinstitution of DMARD treatment in these patients. ${ }^{[129]}$ It was shown in another study that remission was observed for at least one year in nearly $15 \%$ of patients after the discontinuation of DMARDs, and symptom duration and laboratory activation markers were important for their prognosis. ${ }^{[133]}$ Many studies have demonstrated that differences exist between patients and their treating physicians regarding attitudes toward the disease. While fatigue and pain are important complaints for the patient, physicians focus more on tender and swollen joint count. As the main goal of RA management is to reduce disability and improve quality of life, these two perspectives should also be considered when planning treatment. ${ }^{[134]}$ Treatment compliance and response have been shown to be better in patients with RA when treatment planning is performed taking the patient's characteristics and preferences into account. ${ }^{[135-137]}$ Adjustments in DMARD doses can be made considering these aspects and with the patient's input. ${ }^{[1]}$ Our expert committee strongly supports this statement.

14. Different factors such as progression of structural damage, accompanying diseases, and safety issues should also be considered during treatment planning. Disability due to RA may not be associated solely with disease activity. It can also be related to extraarticular involvement or comorbidities such as cardiovascular disease and lymphoma. ${ }^{[12,137]}$
Disease-modifying antirheumatic drugs along with biological agents act by immune system suppression and may be associated with increased susceptibility to infections and cancers. ${ }^{[138]}$ Although rarely seen, lifethreatening, serious, adverse effects may occur. ${ }^{[139,140]}$ Therefore, it has been emphasized in all guidelines on the use of DMARDs and biological agents in patients with RA that safety issues should be considered as much as efficacy. ${ }^{[110,141]}$ Progression of structural damage in patients with RA is closely associated with factors such as ESR, CRP, anti-CCP levels, and female gender. ${ }^{[142]}$ The ACR and EULAR guidelines on management of RA emphasized that factors such as safety and cost should be considered when using DMARDs and biological agents. ${ }^{[1,3]}$ It is also recommended that each patient should be carefully assessed before treatment is initiated. Also, all of the measurements and screening examinations should be performed as required for the specific therapeutic agent, cautions and contraindications should be determined, and necessary examinations should be performed according to the suggested algorithm for toxicity follow-up. ${ }^{[1,3,136,143]}$ For example, all patients should be screened for tuberculosis and hepatitis before the initiation of biological agents. Contraindications should be determined, and prophylaxis should be administered, if necessary, in patients before treatment initiation. Also, all potential candidates for treatment with biological agents should be assessed in detail for lymphoproliferative and demyelinating diseases along with heart diseases. The patients also should especially be monitored for infections and malignancies. ${ }^{[3,144]}$ Similarly, all patients should be carefully assessed and examined with all necessary evaluations having been completed before GC and DMARD treatment. ${ }^{[1,3,66]}$ All physicians caring for patients with RA should be well-informed about drugs and their monitoring instructions. Considering all of the above-mentioned features, our expert committee strongly supports this statement.

\section{Intraarticular local corticosteroids can be} used in cases of monoarthritis. Corticosteroids have been used for years in the management of RA, and they act by suppressing disease activity. Unlike other DMARDs, steroids can also be effective via intraarticular administration. Intraarticular steroids are recommended when disease activity is limited to one or a few joints. ${ }^{[145]}$ Intraarticular corticosteroids have been associated with successful outcomes in cases of persistent monoarthritis in patients with RA..$^{[145-147]}$ It was reported in a systematic review that intraarticular 
steroids provided some beneficial effects with regard to knee pain, limitation of motion, walking distance, and morning stiffness. ${ }^{[146]}$ It has also been shown that triamcinolone hexacetonide is the most effective and longest-acting molecule among intraarticular steroids used in the knee joint. ${ }^{[147]}$ However, there is no evidence to support that intraarticular injections reduce structural joint damage. Triamcinolone hexacetonide has also been recommended to be used via intraarticular injection due to a low solubility and long half-life within the joint. Care should be taken to ensure that the needle is correctly inserted within the joint, and the procedure can be guided by imaging techniques if needed. For safety reasons, a maximum of three to four injections per year is recommended, and weight-bearing joints should be rested after the injection for at least 24 hours. ${ }^{[145]}$ Studies have shown that intraarticular injection of steroids may lead to adverse events similar to systemic administration. ${ }^{[148]}$ However, these adverse reactions are restricted and not long-lasting. Intraarticular injections should be performed with caution in patients with comorbidities like diabetes and arterial hypertension, and patients should be warned about possible transient hyperglycemia and an increase in blood pressure. ${ }^{[148]}$ Taking all of the above-mentioned evidence into account, our expert committee supports this statement by $8.5 / 10$.

16. Patient specific exercises, assistive and adaptive devices, protective and/or corrective ortheses, physical therapy modalities, balneotherapy, spa therapy, and hydrotherapy should be used as non-pharmacological treatments in RA. Rehabilitation interventions, including exercise, physical therapy modalities, balneotherapy, spa therapy, and hydrotherapy, constitute non-pharmacological treatment modalities which play a significant role in the management of patients with RA. In recent years, data on physiotherapy and rehabilitation interventions in the management of RA have continued to accumulate, and physiotherapy has been recommended in most of the national and international guidelines. ${ }^{[149-151]}$

Meta-analyses and systematic reviews demonstrating the effectiveness of exercises specifically designed for individual patients with RA have emphasized that range of motion and strengthening exercises in addition to patient education and joint protection programs are important in achieving treatment goals and maintaining joint functions. ${ }^{[149-152]}$ Most guidelines on the management of RA strongly recommend exercise treatments. ${ }^{[143,153,154]}$ Increased joint mobility and muscle strength, improved aerobic fitness, functions, and psychological well-being without an increase in fatigue and joint symptoms have been reported in patients with RA who were regularly involved in dynamic and aerobic exercise programs. ${ }^{[155]}$ Aerobic exercise has been shown to be effective in coping with rheumatoid disease by increasing muscle strength, endurance, and aerobic capacity. ${ }^{[150,155-157]}$ Moderate to high intensity aerobic activities, including weight-bearing exercises designed according to the patient's general health and joint status, should be recommended in order to increase cardiovascular endurance in all patients with RA..$^{[157-159]}$

Dynamic exercises and hydrotherapy are recommended in addition to pharmacological treatments in patients with early arthritis. ${ }^{[152,160,161]}$ These patients should be encouraged to perform strengthening exercises and suitable sports activities in conjunction with joint protection programs. ${ }^{[160,161]}$ Exercise programs designed according to the general status and rheumatic disease activity of the patient also constitute an essential part of the management of patients with RA in combination with pharmacological treatment in our country.

There is moderate evidence regarding the short and long-term efficacy of protective and/or corrective ortheses as well as the use of assistive and adaptive devices on pain and functions in RA. ${ }^{[150,155,162]}$ There is limited evidence suggesting that static hand and wrist splints lead to pain reduction in patients with RA, and there is no evidence to suggest that any positive effects associated with these splints improves range of motion (ROM), grip strength, or ulnar deviation. ${ }^{[151,163]}$ There is strong evidence to support that hand-wrist splints or hand-wrist supports worn during work provide shortterm pain reduction and increased grip strength. Their effectiveness is related to the amount of time they are worn (Evidence level: IA). ${ }^{[162]}$ It was reported that wrist splints worn during work-related activities were highly effective in the reduction of wrist pain at the end of a four-week period in patients with arthritis of the wrist joint (Evidence level: 1B). ${ }^{[164]}$ In a randomized controlled study by Silva et al. ${ }^{[165]}$ it was reported that night and daytime use of a hand positioning splint reduced pain, increased grip and pinch strength, and improved functional status at the end of three months in patients with RA (Evidence level: IB). There are also studies suggesting that metacarpophalangeal splints and finger splints are mildly effective for improving pain, dexterity, strength, and function (Evidence level: IB, IIB).$^{[166,167]}$ 
In contrast, some studies suggested that static wrist splints were not effective on pain, function, or deformity. They were also proved to be not effective with regard to activities of daily living and occupational performance at the end of one year. ${ }^{[163,168,169]}$ (Evidence level: IIB, IB). Again, in some reviews, assistive devices and splints along with hand and foot ortheses have not been found to be effective on the patient's functional status. ${ }^{[170]}$

There is strong evidence suggesting that shoe modification and custom-made foot ortheses are effective in both the short-term and long-term in patients with foot deformities; however, foot ortheses have not been shown to be effective in metatarsophalangeal joint pain (Evidence level: IA). ${ }^{[162,171]}$

Diverse results can be noted regarding the effectiveness of physical treatment modalities in patients with RA. According to the British Society for Rheumatology (BSR) and British Health Professionals in Rheumatology (BHPR) guidelines, hydrotherapy, thermotherapy, and transcutaneous nerve stimulation (TENS) are recommended as assistive treatment methods for early arthritis. ${ }^{[154]}$ Physical treatment modalities have not been included in the EULAR guidelines. ${ }^{[143]}$ Professional opinions and recommendations regarding the effectiveness of thermotherapy and physical treatment modalities can be found in the literature. ${ }^{[151]}$ Thermotherapy and TENS have been recommended for use in addition to pharmacological treatment in guidelines for RA treatment. ${ }^{[143,149,152,154,172]}$ Ultrasound (US) and laser treatments applied during the inactive disease period have been suggested to be effective and may be used in addition to drug treatment in the two main guidelines. ${ }^{[143,149,172]}$ However, none of the guidelines provide standardized recommendations for the method, intensity, and duration of these modalities. Well-designed, high-quality studies are needed in order to develop a standardized treatment approach.

Studies of low levels of evidence exist on balneotherapy and spa therapies (Evidence level: C).$^{[149,151,155,172]}$ Balneotherapy has been recommended in addition to active and passive physiotherapy in one of the guidelines and has been reported to be effective. ${ }^{[173]}$

Since most of the physicians treating patients with RA are PM\&R specialists in our country, the patient approach may differ compared with the practices and guidelines in other countries. The experts who participated in this project aimed to propose recommendations using a holistic approach to improve patients' quality of life. This goal should be achieved not only by pharmacological treatments, but also by non-pharmacological interventions, including recommendations for exercise, physical therapy, assistive devices, and ortheses. Turkey is located in an exceptional geographic location which provides substantial access to thermal waters; therefore, balneotherapy and spa therapies, provided they are administered during a suitable disease activity level, have been observed to be effective by many physicians caring for RA patients here. Our group underscores the necessity for well-designed, high-quality studies in the field of physical therapy and rehabilitation of patients with RA.

\section{Declaration of conflicting interests}

The authors declared no conflicts of interest with respect to the authorship and/or publication of this article.

\section{Funding}

The authors received no financial support for the research and/or authorship of this article.

\section{REFERENCES}

1. Smolen JS, Landewé R, Breedveld FC, Dougados M, Emery P, Gaujoux-Viala C, et al. EULAR recommendations for the management of rheumatoid arthritis with synthetic and biological disease-modifying antirheumatic drugs. Ann Rheum Dis 2010;69:964-75.

2. Smolen JS, Aletaha D, Bijlsma JW, Breedveld FC, Boumpas D, Burmester G, et al. Treating rheumatoid arthritis to target: recommendations of an international task force. Ann Rheum Dis 2010 ;69:631-7.

3. Saag KG, Teng GG, Patkar NM, Anuntiyo J, Finney C, Curtis JR, et al. American College of Rheumatology 2008 recommendations for the use of nonbiologic and biologic disease-modifying antirheumatic drugs in rheumatoid arthritis. Arthritis Rheum 2008;59:762-84.

4. Furst DE, Keystone EC, Fleischmann R, Mease P, Breedveld FC, Smolen JS, et al. Updated consensus statement on biological agents for the treatment of rheumatic diseases, 2009. Ann Rheum Dis 2010;69 Suppl 1:i2-29.

5. Oxford Centre for Evidince Based Medicine. Levels of Evidence; March 2009. Abailable from: http://www2. cch.org.tw/ebm/file/CEBM-Levels-of-Evidence.pdf

6. Linstone HA, Turoff M. The Delphi Method: Techniques and Applications. Reading, Massachusetts: AdisonWesley; 1975.

7. Tababet Uzmanlık Tüzüğü. Resmi Gazete 18 Nisan 1973; Sayı: 14511, Tababet Uzmanlık Dalları, Yan Dalları ve Asistanlık Süreleri: Madde 5 - (Degişik: 5 Temmuz 1983 - 83/6834 K.) 
8. Tipta Uzmanlık Tüzüğü 2002. Resmi Gazete Tarihi: 19 Haziran 2002, Sayı: 24790, Karar Sayıs1: 2002/4198.

9. Riemsma RP, Kirwan JR, Taal E, Rasker JJ. Patient education for adults with rheumatoid arthritis. Cochrane Database Syst Rev 2003;CD003688.

10. Hammond A, Freeman K. One-year outcomes of a randomized controlled trial of an educationalbehavioural joint protection programme for people with rheumatoid arthritis. Rheumatology (Oxford) 2001;40:1044-51.

11. Masiero S, Boniolo A, Wassermann L, Machiedo H, Volante D, Punzi L. Effects of an educational-behavioral joint protection program on people with moderate to severe rheumatoid arthritis: a randomized controlled trial. Clin Rheumatol 2007;26:2043-50.

12. Iversen MD. Arthritis patient education and team approaches to management. In: Hochberg MC, Silman AJ, Smolen JS, Weinblatt ME, Weisman MH, editors. Rheumatology. Philadelphia: Elsevier; 2011. p. 427-32.

13. van der Heide A, Jacobs JW, Bijlsma JW, Heurkens $\mathrm{AH}$, van Booma-Frankfort C, van der Veen MJ, et al. The effectiveness of early treatment with "second-line" antirheumatic drugs. A randomized, controlled trial. Ann Intern Med 1996;124:699-707.

14. Orlewska E, Ancuta I, Anic B, Codrenau C, Damjanov $\mathrm{N}$, Djukic P, et al. Access to biologic treatment for rheumatoid arthritis in Central and Eastern European (CEE) countries. Med Sci Monit 2011;17:SR1-13.

15. Suarez-Almazor ME, Belseck E, Shea B, Wells G, Tugwell P. Sulfasalazine for rheumatoid arthritis. Cochrane Database Syst Rev 2000;CD000958.

16. Jeurissen ME, Boerbooms AM, van de Putte LB, Doesburg WH, Mulder J, Rasker JJ, et al. Methotrexate versus azathioprine in the treatment of rheumatoid arthritis. A forty-eight-week randomized, double-blind trial. Arthritis Rheum 1991;34:961-72.

17. Strand V, Tugwell P, Bombardier C, Maetzel A, Crawford B, Dorrier C, et al. Function and health-related quality of life: results from a randomized controlled trial of leflunomide versus methotrexate or placebo in patients with active rheumatoid arthritis. Leflunomide Rheumatoid Arthritis Investigators Group. Arthritis Rheum 1999;42:1870-8.

18. Dudler J, Möller B, Michel BA, Villiger PM. Biologics in rheumatoid arthritis-recommendations for Swiss practice. Swiss Med Wkly 2011;141:w13189.

19. Montag K, Gingold M, Boers A, Littlejohn G. Diseasemodifying anti-rheumatic drug usage, prescribing patterns and disease activity in rheumatoid arthritis patients in community-based practice. Intern Med J 2011;41:450-5.

20. Conaghan PG, Hensor EM, Keenan AM, Morgan AW, Emery P; YEAR Consortium. Persistently moderate DAS-28 is not benign: loss of function occurs in early RA despite step-up DMARD therapy. Rheumatology (Oxford) 2010;49:1894-9.
21. Möttönen T, Hannonen $\mathrm{P}$, Leirisalo-Repo $\mathrm{M}$, Nissilä $\mathrm{M}$, Kautiainen $\mathrm{H}$, Korpela $\mathrm{M}$, et al. Comparison of combination therapy with single-drug therapy in early rheumatoid arthritis: a randomised trial. FIN-RACo trial group. Lancet 1999;353:1568-73.

22. Grigor C, Capell H, Stirling A, McMahon AD, Lock P, Vallance R, et al. Effect of a treatment strategy of tight control for rheumatoid arthritis (the TICORA study): a single-blind randomised controlled trial. Lancet 2004;364:263-9.

23. Allaart CF, Goekoop-Ruiterman YP, de Vries-Bouwstra JK, Breedveld FC, Dijkmans BA; FARR study group. Aiming at low disease activity in rheumatoid arthritis with initial combination therapy or initial monotherapy strategies: the BeSt study. Clin Exp Rheumatol 2006;24:S-77-82.

24. Verstappen SM, Jacobs JW, van der Veen MJ, Heurkens $\mathrm{AH}$, Schenk Y, ter Borg EJ, et al. Intensive treatment with methotrexate in early rheumatoid arthritis: aiming for remission. Computer Assisted Management in Early Rheumatoid Arthritis (CAMERA, an open-label strategy trial). Ann Rheum Dis 2007;66:1443-9.

25. Mclnnes IB, Jacobs JWG, Woodburn J, Jacob $M$ van Laar. Tratment of rheumatoid arthritis. In: Bijlsma JWJ, Burmester GR, Silva JAP, Faarvang KL, Hachulla E, Mariette X, editors. EULAR Compendium on rheumatic diseases. London: BMJ Publishing Group; 2009. p. 81-91.

26. Rath T, Rubbert A. Drug combinations with methotrexate to treat rheumatoid arthritis. Clin Exp Rheumatol 2010;28:S52-7.

27. Aletaha D, Smolen JS. The rheumatoid arthritis patient in the clinic: comparing more than 1,300 consecutive DMARD courses. Rheumatology (Oxford) 2002;41:1367-74.

28. Katchamart W, Trudeau J, Phumethum V, Bombardier C. Efficacy and toxicity of methotrexate (MTX) monotherapy versus MTX combination therapy with non-biological disease-modifying antirheumatic drugs in rheumatoid arthritis: a systematic review and meta-analysis. Ann Rheum Dis 2009;68:1105-12.

29. Katchamart W, Trudeau J, Phumethum V, Bombardier C. Methotrexate monotherapy versus methotrexate combination therapy with nonbiologic disease modifying anti-rheumatic drugs for rheumatoid arthritis. Cochrane Database Syst Rev 2010;CD008495.

30. Krüger K. Combination therapy using methotrexate with DMARDs or biologics-current status. Z Rheumatol 2011;70:114-22. [Abstract]

31. Rau R, Schleusser B, Herborn G, Karger T. Longterm combination therapy of refractory and destructive rheumatoid arthritis with methotrexate (MTX) and intramuscular gold or other disease modifying antirheumatic drugs compared to MTX monotherapy. J Rheumatol 1998 ;25:1485-92.

32. Oliver AM, St.Clair EW. Rheumatoid arthritis/treatment and assesment. In: Klippel JH, editor. Primer on rheumatic diseases. Atlanta: Springer; 2008. p. 133-41. 
33. Ma MH, Kingsley GH, Scott DL. A systematic comparison of combination DMARD therapy and tumour necrosis inhibitor therapy with methotrexate in patients with early rheumatoid arthritis. Rheumatology (Oxford) 2010;49:91-8.

34. Chen YF, Jobanputra P, Barton P, Jowett S, Bryan S, Clark W, et al. A systematic review of the effectiveness of adalimumab, etanercept and infliximab for the treatment of rheumatoid arthritis in adults and an economic evaluation of their cost-effectiveness. Health Technol Assess 2006;10:iii-iv, xi-xiii, 1-229.

35. Anderson PJ. Tumor necrosis factor inhibitors: clinical implications of their different immunogenicity profiles. Semin Arthritis Rheum 2005;34:19-22.

36. Behrens F, Koehm M, Burkhardt H. Update 2011: leflunomide in rheumatoid arthritis-strengths and weaknesses. Curr Opin Rheumatol 2011;23:282-7.

37. Kunkel G, W Cannon G. Leflunomide in the treatment of rheumatoid arthritis. Expert Rev Clin Immunol 2006;2:17-31.

38. Sharp JT, Strand V, Leung H, Hurley F, Loew-Friedrich I. Treatment with leflunomide slows radiographic progression of rheumatoid arthritis: results from three randomized controlled trials of leflunomide in patients with active rheumatoid arthritis. Leflunomide Rheumatoid Arthritis Investigators Group. Arthritis Rheum 2000;43:495-505.

39. Larsen A, Kvien TK, Schattenkirchner M, Rau R, Scott DL, Smolen JS, et al. Slowing of disease progression in rheumatoid arthritis patients during long-term treatment with leflunomide or sulfasalazine. Scand J Rheumatol 2001;30:135-42.

40. Strand V, Tugwell P, Bombardier C, Maetzel A, Crawford B, Dorrier C, et al. Function and health-related quality of life: results from a randomized controlled trial of leflunomide versus methotrexate or placebo in patients with active rheumatoid arthritis. Leflunomide Rheumatoid Arthritis Investigators Group. Arthritis Rheum 1999;42:1870-8.

41. Strand V, Scott DL, Emery P, Kalden JR, Smolen JS, Cannon GW, et al. Physical function and health related quality of life: analysis of 2-year data from randomized, controlled studies of leflunomide, sulfasalazine, or methotrexate in patients with active rheumatoid arthritis. J Rheumatol 2005;32:590-601.

42. Sulfasalazine in early rheumatoid arthritis. The Australian Multicentre Clinical Trial Group. J Rheumatol 1992;19:1672-7.

43. Hannonen $\mathrm{P}$, Möttönen $\mathrm{T}$, Hakola $\mathrm{M}$, Oka $\mathrm{M}$. Sulfasalazine in early rheumatoid arthritis. A 48-week double-blind, prospective, placebo-controlled study. Arthritis Rheum 1993;36:1501-9.

44. Williams HJ, Ward JR, Dahl SL, Clegg DO, Willkens RF, OglesbyT, etal.A controlled trialcomparing sulfasalazine, gold sodium thiomalate, and placebo in rheumatoid arthritis. Arthritis Rheum 1988;31:702-13.
45. Rains CP, Noble S, Faulds D. Sulfasalazine. A review of its pharmacological properties and therapeutic efficacy in the treatment of rheumatoid arthritis. Drugs 1995;50:137-56.

46. Weinblatt ME, Reda D, Henderson W, Giobbie-Hurder A, Williams D, Diani A, et al. Sulfasalazine treatment for rheumatoid arthritis: a metaanalysis of 15 randomized trials. J Rheumatol 1999;26:2123-30.

47. Jones G, Halbert J, Crotty M, Shanahan EM, Batterham M, Ahern M. The effect of treatment on radiological progression in rheumatoid arthritis: a systematic review of randomized placebo-controlled trials. Rheumatology (Oxford) 2003;42:6-13.

48. Aviña-Zubieta JA, Galindo-Rodriguez G, Newman S, Suarez-Almazor ME, Russell AS. Long-term effectiveness of antimalarial drugs in rheumatic diseases. Ann Rheum Dis 1998;57:582-7.

49. Suarez-Almazor ME, Belseck E, Shea B, Homik J, Wells G, Tugwell P. Antimalarials for rheumatoid arthritis. Cochrane Database Syst Rev 2000;CD000959.

50. Rantalaiho V, Korpela M, Laasonen L, Kautiainen H, Järvenpää S, Hannonen $\mathrm{P}$, et al. Early combination disease-modifying antirheumatic drug therapy and tight disease control improve long-term radiologic outcome in patients with early rheumatoid arthritis: the 11-year results of the Finnish Rheumatoid Arthritis Combination Therapy trial. Arthritis Res Ther 2010;12:R122.

51. Tosh JC, Wailoo AJ, Scott DL, Deighton CM. Costeffectiveness of combination nonbiologic diseasemodifying antirheumatic drug strategies in patients with early rheumatoid arthritis. J Rheumatol 2011;38:1593-600.

52. Boers M, Verhoeven AC, Markusse HM, van de Laar MA, Westhovens R, van Denderen JC, et al. Randomised comparison of combined step-down prednisolone, methotrexate and sulphasalazine with sulphasalazine alone in early rheumatoid arthritis. Lancet 1997;350:309-18.

53. Hetland ML, Stengaard-Pedersen K, Junker $P$, Lottenburger $\mathrm{T}$, Ellingsen $\mathrm{T}$, Andersen LS, et al. Combination treatment with methotrexate, cyclosporine, and intraarticular betamethasone compared with methotrexate and intraarticular betamethasone in early active rheumatoid arthritis: an investigator-initiated, multicenter, randomized, double-blind, parallelgroup, placebo-controlled study. Arthritis Rheum 2006;54:1401-9.

54. Möttönen T, Hannonen P, Korpela M, Nissilä M, Kautiainen $\mathrm{H}$, Ilonen $\mathrm{J}$, et al. Delay to institution of therapy and induction of remission using single-drug or combination-disease-modifying antirheumatic drug therapy in early rheumatoid arthritis. Arthritis Rheum 2002;46:894-8.

55. Dougados $\mathrm{M}$, Combe B, Cantagrel A, Goupille P, Olive P, Schattenkirchner M, et al. Combination therapy in early rheumatoid arthritis: a randomised, controlled, double blind 52 week clinical trial of sulphasalazine and methotrexate compared with the single componentS. Ann Rheum Dis 1999;58:220-5. 
56. Haagsma CJ, van Riel PL, de Jong AJ, van de Putte LB. Combination of sulphasalazine and methotrexate versus the single components in early rheumatoid arthritis: a randomized, controlled, double-blind, 52 week clinical trial. Br J Rheumatol 1997;36:1082-8.

57. Calgüneri M, Pay S, Calişkaner Z, Apraş S, Kiraz S, Ertenli I, et al. Combination therapy versus monotherapy for the treatment of patients with rheumatoid arthritis. Clin Exp Rheumatol 1999;17:699-704.

58. Saunders SA, Capell HA, Stirling A, Vallance R, Kincaid W, McMahon AD, et al. Triple therapy in early active rheumatoid arthritis: a randomized, single-blind, controlled trial comparing step-up and parallel treatment strategies. Arthritis Rheum 2008;58:1310-7.

59. Bijlsma JW, van der Goes MC, Hoes JN, Jacobs JW, Buttgereit F, Kirwan J. Low-dose glucocorticoid therapy in rheumatoid arthritis: an obligatory therapy. Ann N Y Acad Sci 2010;1193:123-6.

60. Gorter SL, Bijlsma JW, Cutolo M, Gomez-Reino J, Kouloumas M, Smolen JS, et al. Current evidence for the management of rheumatoid arthritis with glucocorticoids: a systematic literature review informing the EULAR recommendations for the management of rheumatoid arthritis. Ann Rheum Dis 2010;69:1010-4.

61. Mouterde G, Dernis E, Ruyssen-Witrand A, Claudepierre P, Schaeverbeke T, Cantagrel A, et al. Indications of glucocorticoids in early arthritis and rheumatoid arthritis: recommendations for clinical practice based on data from the literature and expert opinion. Joint Bone Spine 2010;77:597-603.

62. National Collaborating Centre for Chronic Conditions (UK). Rheumatoid Arthritis: National Clinical Guideline for Management and Treatment in Adults. London: Royal College of Physicians (UK); 2009 Feb:135-141.National Institute for Health and Clinical Excellence: Guidance.

63. Hoes JN, Jacobs JW, Verstappen SM, Bijlsma JW, Van der Heijden GJ. Adverse events of low- to medium-dose oral glucocorticoids in inflammatory diseases: a metaanalysis. Ann Rheum Dis 2009 ;68:1833-8.

64. Haraoui B, Pope J. Treatment of early rheumatoid arthritis: concepts in management. Semin Arthritis Rheum 2011;40:371-88.

65. van Leeuwen MA, van Rijswijk $M H$, van der Heijde DM, Te Meerman GJ, van Riel PL, Houtman PM, et al. The acute-phase response in relation to radiographic progression in early rheumatoid arthritis: a prospective study during the first three years of the disease. Br J Rheumatol 1993;32 Suppl 3:9-13.

66. Vastesaeger N, Xu S, Aletaha D, St Clair EW, Smolen JS. A pilot risk model for the prediction of rapid radiographic progression in rheumatoid arthritis. Rheumatology (Oxford) 2009;48:1114-21.

67. Westhovens R, Robles M, Ximenes AC, Nayiager S, Wollenhaupt J, Durez P, et al. Clinical efficacy and safety of abatacept in methotrexate-naive patients with early rheumatoid arthritis and poor prognostic factors. Ann Rheum Dis 2009;68:1870-7.
68. Bathon JM, Martin RW, Fleischmann RM, Tesser JR, Schiff MH, Keystone EC, et al. A comparison of etanercept and methotrexate in patients with early rheumatoid arthritis. N Engl J Med 2000;343:1586-93.

69. St Clair EW, van der Heijde DM, Smolen JS, Maini RN, Bathon JM, Emery P, et al. Combination of infliximab and methotrexate therapy for early rheumatoid arthritis: a randomized, controlled trial. Arthritis Rheum 2004;50:3432-43.

70. Breedveld FC, Weisman MH, Kavanaugh AF, Cohen SB, Pavelka K, van Vollenhoven $\mathrm{R}$, et al. The PREMIER study: A multicenter, randomized, double-blind clinical trial of combination therapy with adalimumab plus methotrexate versus methotrexate alone or adalimumab alone in patients with early, aggressive rheumatoid arthritis who had not had previous methotrexate treatment. Arthritis Rheum 2006;54:26-37.

71. Emery P, Genovese MC, van Vollenhoven R, Sharp JT, Patra K, Sasso EH. Less radiographic progression with adalimumab plus methotrexate versus methotrexate monotherapy across the spectrum of clinical response in early rheumatoid arthritis. J Rheumatol 2009;36:1429-41.

72. Kuriya B, Arkema EV, Bykerk VP, Keystone EC. Efficacy of initial methotrexate monotherapy versus combination therapy with a biological agent in early rheumatoid arthritis: a meta-analysis of clinical and radiographic remission. Ann Rheum Dis 2010;69:1298-304.

73. Goekoop-Ruiterman YP, de Vries-Bouwstra JK, Allaart CF, van Zeben D, Kerstens PJ, Hazes JM, et al. Clinical and radiographic outcomes of four different treatment strategies in patients with early rheumatoid arthritis (the BeSt study): a randomized, controlled trial. Arthritis Rheum 2005 ;52:3381-90.

74. Carswell EA, Old LJ, Kassel RL, Green S, Fiore N, Williamson B. An endotoxin-induced serum factor that causes necrosis of tumors. Proc Natl Acad Sci U S A 1975;72:3666-70.

75. Maini RN, Breedveld FC, Kalden JR, Smolen JS, Davis D, Macfarlane JD, et al. Therapeutic efficacy of multiple intravenous infusions of anti-tumor necrosis factor alpha monoclonal antibody combined with low-dose weekly methotrexate in rheumatoid arthritis. Arthritis Rheum 1998 ;41:1552-63.

76. Moreland LW, Schiff MH, Baumgartner SW, Tindall EA, Fleischmann RM, Bulpitt KJ, et al. Etanercept therapy in rheumatoid arthritis. A randomized, controlled trial. Ann Intern Med 1999;130:478-86.

77. Weinblatt ME, Kremer JM, Bankhurst AD, Bulpitt KJ, Fleischmann RM, Fox RI, et al. A trial of etanercept, a recombinant tumor necrosis factor receptor:Fc fusion protein, in patients with rheumatoid arthritis receiving methotrexate. N Engl J Med 1999;340:253-9.

78. Klareskog L, van der Heijde D, de Jager JP, Gough A, Kalden J, Malaise M, et al. Therapeutic effect of the combination of etanercept and methotrexate compared with each treatment alone in patients with rheumatoid arthritis: double-blind randomised controlled trial. Lancet 2004;363:675-81. 
79. Weinblatt ME, Keystone EC, Furst DE, Moreland LW, Weisman MH, Birbara CA, et al. Adalimumab, a fully human anti-tumor necrosis factor alpha monoclonal antibody, for the treatment of rheumatoid arthritis in patients taking concomitant methotrexate: the ARMADA trial. Arthritis Rheum 2003;48:35-45.

80. Mpofu S, Fatima F, Moots RJ. Anti-TNF-alpha therapies: they are all the same (aren't they?). Rheumatology (Oxford) 2005;44:271-3.

81. Lutt JR, Deodhar A. Rheumatoid arthritis: strategies in the management of patients showing an inadequate response to TNFalpha antagonists. Drugs 2008;68:591606.

82. Virkki LM, Valleala H, Takakubo Y, Vuotila J, Relas H, Komulainen R, et al. Outcomes of switching anti-TNF drugs in rheumatoid arthritis-a study based on observational data from the Finnish Register of Biological Treatment (ROB-FIN). Clin Rheumatol 2011;30:1447-54.

83. Scrivo R, Conti F, Spinelli FR, Truglia S, Magrini L, Di Franco M, et al. Switching between TNFalpha antagonists in rheumatoid arthritis: personal experience and review of the literature. Reumatismo 2009;61:107-17.

84. Karlsson JA, Kristensen LE, Kapetanovic MC, Gülfe A, Saxne T, Geborek P. Treatment response to a second or third TNF-inhibitor in RA: results from the South Swedish Arthritis Treatment Group Register. Rheumatology (Oxford) 2008;47:507-13.

85. Hyrich KL, Lunt $M$, Watson KD, Symmons DP, Silman AJ; British Society for Rheumatology Biologics Register. Outcomes after switching from one anti-tumor necrosis factor alpha agent to a second anti-tumor necrosis factor alpha agent in patients with rheumatoid arthritis: results from a large UK national cohort study. Arthritis Rheum 2007;56:13-20.

86. Bartelds GM, Wijbrandts CA, Nurmohamed MT, Stapel S, Lems WF, Aarden L, et al. Anti-infliximab and anti-adalimumab antibodies in relation to response to adalimumab in infliximab switchers and anti-tumour necrosis factor naive patients: a cohort study. Ann Rheum Dis 2010;69:817-21.

87. Hjardem E, Østergaard M, Pødenphant J, Tarp U, Andersen LS, Bing J, et al. Do rheumatoid arthritis patients in clinical practice benefit from switching from infliximab to a second tumor necrosis factor alpha inhibitor? Ann Rheum Dis 2007;66:1184-9.

88. Lee YH, Bae SC, Song GG. The efficacy and safety of rituximab for the treatment of active rheumatoid arthritis: a systematic review and meta-analysis of randomized controlled trials. Rheumatol Int 2011;31:1493-9.

89. Buch MH, Smolen JS, Betteridge N, Breedveld FC, Burmester G, Dörner $T$, et al. Updated consensus statement on the use of rituximab in patients with rheumatoid arthritis. Ann Rheum Dis 2011;70:909-20.

90. Schiff M, Bessette L. Evaluation of abatacept in biologicnaïve patients with active rheumatoid arthritis. Clin Rheumatol 2010;29:583-91.
91. Kawashiri SY, Kawakami A, Iwamoto N, Fujikawa K, Aramaki T, Tamai M, et al. Switching to the anti-interleukin- 6 receptor antibody tocilizumab in rheumatoid arthritis patients refractory to antitumor necrosis factor biologics. Mod Rheumatol 2010;20:40-5.

92. Nakashima Y, Kondo M, Harada H, Horiuchi T, Ishinishi T, Jojima $\mathrm{H}$, et al. Clinical evaluation of tocilizumab for patients with active rheumatoid arthritis refractory to anti-TNF biologics: tocilizumab in combination with methotrexate. Mod Rheumatol 2010;20:343-52.

93. Singh JA, Beg S, Lopez-Olivo MA. Tocilizumab for rheumatoid arthritis: a Cochrane systematic review. J Rheumatol 2011;38:10-20.

94. Lie E, van der Heijde D, Uhlig T, Mikkelsen K, Kalstad S, Kaufmann C, et al. Treatment strategies in patients with rheumatoid arthritis for whom methotrexate monotherapy has failed: data from the NOR-DMARD register. Ann Rheum Dis 2011;70:2103-10.

95. Wakabayashi H, Oka H, Nishioka Y, Hasegawa $M$, Sudo A, Nishioka K. Do biologics-naïve patients with rheumatoid arthritis respond better to tocilizumab than patients for whom anti-TNF agents have failed? A retrospective study. Clin Exp Rheumatol 2011;29:314-7.

96. Yocum D. Immunological actions of cyclosporin $\mathrm{A}$ in rheumatoid arthritis. Br J Rheumatol 1993;32 Suppl 1:38-41.

97. Kitahara K, Kawai S. Cyclosporine and tacrolimus for the treatment of rheumatoid arthritis. Curr Opin Rheumatol 2007;19:238-45.

98. Tugwell P, Pincus T, Yocum D, Stein M, Gluck O, Kraag G, et al. Combination therapy with cyclosporine and methotrexate in severe rheumatoid arthritis. The Methotrexate-Cyclosporine Combination Study Group. N Engl J Med 1995;333:137-41.

99. Díaz-Borjón A. Guidelines for the use of conventional and newer disease-modifying antirheumatic drugs in elderly patients with rheumatoid arthritis. Drugs Aging 2009;26:273-93.

100. American College of Rheumatology Subcommittee on Rheumatoid Arthritis Guidelines. Guidelines for the management of rheumatoid arthritis: 2002 Update. Arthritis Rheum 2002;46:328-46.

101. Førre O. Radiologic evidence of disease modification in rheumatoid arthritis patients treated with cyclosporine. Results of a 48-week multicenter study comparing lowdose cyclosporine with placebo. Norwegian Arthritis Study Group. Arthritis Rheum 1994;37:1506-12.

102. Gerards AH, Landewé RB, Prins AP, Bruyn GA, Goei Thé HS, Laan RF, et al. Cyclosporin A monotherapy versus cyclosporin $\mathrm{A}$ and methotrexate combination therapy in patients with early rheumatoid arthritis: a double blind randomised placebo controlled trial. Ann Rheum Dis 2003;62:291-6.

103. Sarzi-Puttini P, D’Ingianna E, Fumagalli M, Scarpellini $\mathrm{M}$, Fiorini $\mathrm{T}$, Chérié-Lignière EL, et al. An open, randomized comparison study of cyclosporine $\mathrm{A}$, cyclosporine $\mathrm{A}+$ methotrexate and cyclosporine $\mathrm{A}+$ hydroxychloroquine in the treatment of early severe rheumatoid arthritis. Rheumatol Int 2005;25:15-22. 
104. Shah F, Ali A, Mahmood K. Effectiveness and safety profile of cyclosporine a in rheumatoid arthritis. JPMI 2010;24:259-64.

105. Wells G, Haguenauer D, Shea B, Suarez-Almazor ME, Welch VA, Tugwell P. Cyclosporine for rheumatoid arthritis. Cochrane Database Syst Rev 2000;CD001083.

106. Heurkens AH, Westedt ML, Breedveld FC. Prednisone plus azathioprine treatment in patients with rheumatoid arthritis complicated by vasculitis. Arch Intern Med 1991;151:2249-54.

107. Suarez-Almazor ME, Spooner C, Belseck E. Azathioprine for treating rheumatoid arthritis. Cochrane Database Syst Rev 2000;CD001461.

108. Suarez-Almazor ME, Belseck E, Shea B, Wells G, Tugwell P. Cyclophosphamide for treating rheumatoid arthritis. Cochrane Database Syst Rev 2000;CD001157.

109. Fautrel B, Guillemin F, Meyer O, de Bandt M, Berthelot JM, Flipo RM, et al. Choice of secondline disease-modifying antirheumatic drugs after failure of methotrexate therapy for rheumatoid arthritis: a decision tree for clinical practice based on rheumatologists' preferences. Arthritis Rheum 2009;61:425-34.

110. Nam JL, Winthrop KL, van Vollenhoven RF, Pavelka K, Valesini G, Hensor EM, et al. Current evidence for the management of rheumatoid arthritis with biological disease-modifying antirheumatic drugs: a systematic literature review informing the EULAR recommendations for the management of RA. Ann Rheum Dis 2010;69:976-86.

111. Kauppi MJ, Neva MH, Laiho K, Kautiainen $H$, Luukkainen R, Karjalainen A, et al. Rheumatoid atlantoaxial subluxation can be prevented by intensive use of traditional disease modifying antirheumatic drugs. J Rheumatol 2009;36:273-8.

112. Smolen JS, Aletaha D. Developments in the clinical understanding of rheumatoid arthritis. Arthritis Res Ther 2009;11:204.

113. Landewé RB, Boers M, Verhoeven AC, Westhovens R, van de Laar MA, Markusse HM, et al. COBRA combination therapy in patients with early rheumatoid arthritis: longterm structural benefits of a brief intervention. Arthritis Rheum 2002;46:347-56.

114. Wassenberg S, Rau R, Steinfeld P, Zeidler H. Very lowdose prednisolone in early rheumatoid arthritis retards radiographic progression over two years: a multicenter, double-blind, placebo-controlled trial. Arthritis Rheum 2005;52:3371-80.

115. Möttönen TT, Hannonen PJ, Boers M. Combination DMARD therapy including corticosteroids in early rheumatoid arthritis. Clin Exp Rheumatol 1999;17:S59-65.

116. Kirwan JR, Bijlsma JW, Boers M, Shea BJ. Effects of glucocorticoids on radiological progression in rheumatoid arthritis. Cochrane Database Syst Rev 2007;CD006356.
117. Choy EH, Smith CM, Farewell V, Walker D, Hassell A, Chau L, et al. Factorial randomised controlled trial of glucocorticoids and combination disease modifying drugs in early rheumatoid arthritis. Ann Rheum Dis 2008;67:656-63.

118. O’Dell JR, Leff R, Paulsen G, Haire C, Mallek J, Eckhoff PJ, et al. Treatment of rheumatoid arthritis with methotrexate and hydroxychloroquine, methotrexate and sulfasalazine, or a combination of the three medications: results of a two-year, randomized, doubleblind, placebo-controlled trial. Arthritis Rheum 2002;46:1164-70.

119. Saleem B, Brown AK, Keen H, Nizam S, Freeston J, Karim Z, et al. Disease remission state in patients treated with the combination of tumor necrosis factor blockade and methotrexate or with disease-modifying antirheumatic drugs: A clinical and imaging comparative study. Arthritis Rheum 2009;60:1915-22.

120. Nurmohamed MT, Dijkmans BA. Are biologics more effective than classical disease-modifying antirheumatic drugs? Arthritis Res Ther 2008;10:118.

121. Valesini G, Di Franco M, Spinelli FR, Scrivo R. Induction of remission in rheumatoid arthritis: criteria and opportunities. Rheumatol Int 2008 ;29:131-9.

122. van der Kooij SM, de Vries-Bouwstra JK, GoekoopRuiterman YP, van Zeben D, Kerstens PJ, Gerards AH, et al. Limited efficacy of conventional DMARDs after initial methotrexate failure in patients with recent onset rheumatoid arthritis treated according to the disease activity score. Ann Rheum Dis 2007;66:1356-62.

123. Knevel R, Schoels M, Huizinga TW, Aletaha D, Burmester GR, Combe B, et al. Current evidence for a strategic approach to the management of rheumatoid arthritis with disease-modifying antirheumatic drugs: a systematic literature review informing the EULAR recommendations for the management of rheumatoid arthritis. Ann Rheum Dis 2010;69:987-94.

124. Rantalaiho V, Korpela M, Hannonen P, Kautiainen $H$, Järvenpää S, Leirisalo-Repo M, et al. The good initial response to therapy with a combination of traditional disease-modifying antirheumatic drugs is sustained over time: the eleven-year results of the Finnish rheumatoid arthritis combination therapy trial. Arthritis Rheum 2009;60:1222-31.

125. Ferraccioli GF, Casatta L, Di Poi E, Damato R, Bartoli E. Combination DMARD therapy for rheumatoid arthritis. Full or low DMARD doses? Ann Rheum Dis 1997;56:336-7.

126. Verschueren P, Esselens G, Westhovens R. Daily practice effectiveness of a step-down treatment in comparison with a tight step-up for early rheumatoid arthritis. Rheumatology (Oxford) 2008;47:59-64.

127. Donahue KE, Gartlehner G, Jonas DE, Lux LJ, Thieda P, Jonas BL, et al. Systematic review: comparative effectiveness and harms of disease-modifying medications for rheumatoid arthritis. Ann Intern Med 2008;148:124-34. 
128. Gorter SL, Bijlsma JW, Cutolo M, Gomez-Reino J, Kouloumas M, Smolen JS, et al. Current evidence for the management of rheumatoid arthritis with glucocorticoids: a systematic literature review informing the EULAR recommendations for the management of rheumatoid arthritis. Ann Rheum Dis 2010;69:1010-4.

129. O'Mahony R, Richards A, Deighton C, Scott D. Withdrawal of disease-modifying antirheumatic drugs in patients with rheumatoid arthritis: a systematic review and meta-analysis. Ann Rheum Dis 2010;69:1823-6.

130. Klarenbeek NB, van der Kooij SM, Güler-Yüksel M, van Groenendael JH, Han $\mathrm{KH}$, Kerstens PJ, et al. Discontinuing treatment in patients with rheumatoid arthritis in sustained clinical remission: exploratory analyses from the BeSt study. Ann Rheum Dis 2011;70:315-9.

131. Klarenbeek NB, Güler-Yüksel M, van der Kooij SM, Han KH, Ronday HK, Kerstens PJ, et al. The impact of four dynamic, goal-steered treatment strategies on the 5 -year outcomes of rheumatoid arthritis patients in the BeSt study. Ann Rheum Dis 2011;70:1039-46.

132. van den Broek $M$, Klarenbeek NB, Dirven $L$, van Schaardenburg D, Hulsmans HM, Kerstens PJ, et al. Discontinuation of infliximab and potential predictors of persistent low disease activity in patients with early rheumatoid arthritis and disease activity score-steered therapy: subanalysis of the BeSt study. Ann Rheum Dis 2011;70:1389-94.

133. van der Woude D, Young A, Jayakumar K, Mertens BJ, Toes RE, van der Heijde D, et al. Prevalence of and predictive factors for sustained disease-modifying antirheumatic drug-free remission in rheumatoid arthritis: results from two large early arthritis cohorts. Arthritis Rheum 2009 ;60:2262-71.

134. Edworthy SM. How important is patient selfmanagement? Baillieres Best Pract Res Clin Rheumatol 2000;14:705-14.

135. Iversen MD, Hammond A, Betteridge N. Selfmanagement of rheumatic diseases: state of the art and future perspectives. Ann Rheum Dis 2010;69:955-63.

136. Martin RW, Brower ME, Geralds A, Gallagher PJ, Tellinghuisen DJ. An experimental evaluation of patient decision aid design to communicate the effects of medications on the rate of progression of structural joint damage in rheumatoid arthritis. Patient Educ Couns 2011. [Epub ahead of print]

137. Schoels M, Aletaha D, Smolen JS, Bijlsma JW, Burmester G, Breedveld FC, et al. Follow-up standards and treatment targets in rheumatoid arthritis: results of a questionnaire at the EULAR 2008. Ann Rheum Dis 2010;69:575-8.

138. Salliot C, van der Heijde D. Long-term safety of methotrexate monotherapy in patients with rheumatoid arthritis: a systematic literature research. Ann Rheum Dis 2009;68:1100-4.
139. Singh JA, Wells GA, Christensen R, Tanjong Ghogomu E, Maxwell L, Macdonald JK, et al. Adverse effects of biologics: a network meta-analysis and Cochrane overview. Cochrane Database Syst Rev 2011;CD008794.

140. Zink A, Askling J, Dixon WG, Klareskog L, Silman AJ, Symmons DP. European biologicals registers: methodology, selected results and perspectives. Ann Rheum Dis 2009;68:1240-6.

141. Gaujoux-Viala C, Smolen JS, Landewé R, Dougados M, Kvien TK, Mola EM, et al. Current evidence for the management of rheumatoid arthritis with synthetic disease-modifying antirheumatic drugs: a systematic literature review informing the EULAR recommendations for the management of rheumatoid arthritis. Ann Rheum Dis 2010;69:1004-9.

142. Syversen SW, Gaarder PI, Goll GL, Ødegård S, Haavardsholm EA, Mowinckel P, et al. High anticyclic citrullinated peptide levels and an algorithm of four variables predict radiographic progression in patients with rheumatoid arthritis: results from a 10-year longitudinal study. Ann Rheum Dis 2008;67:212-7.

143. Combe B, Landewe R, Lukas C, Bolosiu HD, Breedveld F, Dougados $\mathrm{M}$, et al. EULAR recommendations for the management of early arthritis: report of a task force of the European Standing Committee for International Clinical Studies Including Therapeutics (ESCISIT). Ann Rheum Dis 2007;66:34-45.

144. Mok CC, Tam LS, Chan TH, Lee GK, Li EK; Hong Kong Society of Rheumatology. Management of rheumatoid arthritis: consensus recommendations from the Hong Kong Society of Rheumatology. Clin Rheumatol 2011;30:303-12.

145. Dernis E, Ruyssen-Witrand A, Mouterde G, Maillefert JF, Tebib J, Cantagrel A, et al. Use of glucocorticoids in rheumatoid arthritis - pratical modalities of glucocorticoid therapy: recommendations for clinical practice based on data from the literature and expert opinion. Joint Bone Spine 2010;77:451-7.

146. Wallen M, Gillies D. Intra-articular steroids and splints/ rest for children with juvenile idiopathic arthritis and adults with rheumatoid arthritis. Cochrane Database Syst Rev 2006;CD002824.

147. Blyth T, Hunter JA, Stirling A. Pain relief in the rheumatoid knee after steroid injection. A singleblind comparison of hydrocortisone succinate, and triamcinolone acetonide or hexacetonide. Br J Rheumatol 1994 ;33:461-3.

148. Habib GS. Systemic effects of intra-articular corticosteroids. Clin Rheumatol 2009;28:749-56.

149. Hurkmans EJ, Jones A, Li LC, Vliet Vlieland TP. Quality appraisal of clinical practice guidelines on the use of physiotherapy in rheumatoid arthritis: a systematic review. Rheumatology (Oxford) 2011;50:1879-88.

150. Vliet Vlieland TP, Pattison D. Non-drug therapies in early rheumatoid arthritis. Best Pract Res Clin Rheumatol 2009;23:103-16. 
151. Forestier R, André-Vert J, Guillez P, Coudeyre E, Lefevre-Colau MM, Combe B, et al. Non-drug treatment (excluding surgery) in rheumatoid arthritis: clinical practice guidelines. Joint Bone Spine 2009;76:691-8.

152. Gossec L, Pavy S, Pham T, Constantin A, Poiraudeau S, Combe B, et al. Nonpharmacological treatments in early rheumatoid arthritis: clinical practice guidelines based on published evidence and expert opinion. Joint Bone Spine 2006;73:396-402.

153. Luqmani R, Hennell S, Estrach C, Birrell F, Bosworth A, Davenport G, et al. British Society for Rheumatology and british health professionals in Rheumatology guideline for the management of rheumatoid arthritis (the first two years). Rheumatology (Oxford) 2006;45:1167-9.

154. Hennell S, Luqmani R. Developing multidisciplinary guidelines for the management of early rheumatoid arthritis. Musculoskeletal Care 2008;6:97-107.

155. Vliet Vlieland TP. Non-drug care for RA-is the era of evidence-based practice approaching? Rheumatology (Oxford) 2007;46:1397-404.

156. Van Den Ende CH, Vliet Vlieland TP, Munneke M, Hazes JM. Dynamic exercise therapy for rheumatoid arthritis. Cochrane Database Syst Rev 2000;CD000322.

157. Stenström $\mathrm{CH}$, Minor MA. Evidence for the benefit of aerobic and strengthening exercise in rheumatoid arthritis. Arthritis Rheum 2003;49:428-34.

158. de Jong Z, Munneke M, Zwinderman AH, Kroon HM, Jansen A, Ronday $\mathrm{KH}$, et al. Is a longterm high-intensity exercise program effective and safe in patients with rheumatoid arthritis? Results of a randomized controlled trial. Arthritis Rheum 2003;48:2415-24.

159. Munneke $M$, de Jong $Z$, Zwinderman AH, Ronday HK, van Schaardenburg D, Dijkmans BA, et al. Effect of a high-intensity weight-bearing exercise program on radiologic damage progression of the large joints in subgroups of patients with rheumatoid arthritis. Arthritis Rheum 2005;53:410-7.

160. Häkkinen A, Sokka T, Hannonen P. A home-based two-year strength training period in early rheumatoid arthritis led to good long-term compliance: a five-year followup. Arthritis Rheum 2004;51:56-62.

161. Hurkmans E, van der Giesen FJ, Vliet Vlieland TP, Schoones J, Van den Ende EC. Dynamic exercise programs (aerobic capacity and/or muscle strength training) in patients with rheumatoid arthritis. Cochrane Database Syst Rev 2009;CD006853.
162. Egan M, Brosseau L, Farmer M, Ouimet MA, Rees S, Wells G, et al. Splints/orthoses in the treatment of rheumatoid arthritis. Cochrane Database Syst Rev 2003;CD004018.

163. Hammond A. Rehabilitation in musculoskeletal diseases. Best Pract Res Clin Rheumatol 2008;22:43549.

164. Veehof MM, Taal E, Heijnsdijk-Rouwenhorst LM, van de Laar MA. Efficacy of wrist working splints in patients with rheumatoid arthritis: a randomized controlled study. Arthritis Rheum 2008;59:1698-704.

165. Silva AC, Jones A, Silva PG, Natour J. Effectiveness of a night-time hand positioning splint in rheumatoid arthritis: a randomized controlled trial. J Rehabil Med 2008;40:749-54.

166. Zijlstra TR, Heijnsdijk-Rouwenhorst L, Rasker JJ. Silver ring splints improve dexterity in patients with rheumatoid arthritis. Arthritis Rheum 2004;51:947-51.

167. van der Giesen FJ, van Lankveld WJ, Kremers-Selten C, Peeters AJ, Stern EB, Le Cessie S, et al. Effectiveness of two finger splints for swan neck deformity in patients with rheumatoid arthritis: a randomized, crossover trial. Arthritis Rheum 2009;61:1025-31.

168. Pagnotta A, Baron M, Korner-Bitensky N. The effect of a static wrist orthosis on hand function in individuals with rheumatoid arthritis. J Rheumatol 1998;25:879-85.

169. Adams J, Burridge J, Mullee M, Hammond A, Cooper C. The clinical effectiveness of static resting splints in early rheumatoid arthritis: a randomized controlled trial. Rheumatology (Oxford) 2008;47:1548-53.

170. Christie A, Jamtvedt G, Dahm KT, Moe RH, Haavardsholm EA, Hagen KB. Effectiveness of nonpharmacological and nonsurgical interventions for patients with rheumatoid arthritis: an overview of systematic reviews. Phys Ther 2007;87:1697-715.

171. Hawke F, Burns J, Radford JA, du Toit V. Custom-made foot orthoses for the treatment of foot pain. Cochrane Database Syst Rev 2008; CD006801.

172. Verhagen AP, Bierma-Zeinstra SM, Cardoso JR, de Bie RA, Boers M, de Vet HC. Balneotherapy for rheumatoid arthritis. Cochrane Database Syst Rev 2003;CD000518.

173. Ottawa Panel. Ottawa Panel Evidence-Based Clinical Practice Guidelines for Electrotherapy and Thermotherapy Interventions in the Management of Rheumatoid Arthritis in Adults. Phys Ther 2004;84:1016-43. 